\title{
The High Arctic geopotential stress field and its implications for the geodynamic evolution
}

\author{
Christian Schiffer ${ }^{1 *}$, Christian Tegner ${ }^{2}$, Andrew J. Schaeffer ${ }^{3}$, Victoria Pease ${ }^{4}$, Søren B. \\ Nielsen ${ }^{2}$ \\ ${ }^{1}$ Department of Earth Sciences, Durham University, Durham DH1 3LE, UK \\ ${ }^{2}$ Centre of Earth System Petrology, Department of Geoscience, Aarhus University, 8000 \\ Aarhus, Denmark \\ ${ }^{3}$ Department of Earth and Environmental Sciences, University of Ottawa, 120 \\ University, Ottawa ON Canada, K1N 6N5 \\ ${ }^{4}$ Department of Geological Sciences, Stockholm University, 106 91, Sweden \\ *Corresponding Author (email: christian.schiffer@zoho.com)
}

\section{Abstract}

We use new models of crustal structure and the depth of the lithosphere-asthenosphere boundary to calculate geopotential energy and its corresponding geopotential stress field for the High Arctic. Palaeo-stress indicators such as dykes and rifts of known age are used to compare the present-day and palaeo stress field. When both stress fields coincide, a minimum age for the configuration of the lithospheric stress field may be defined. We identify three regions in which this is observed. In North Greenland and the eastern Amerasia Basin the stress field is likely the same as during the late Cretaceous. In western Siberia, the stress field is similar to that of the Triassic. The stress directions on the eastern Russian Arctic shelf and the Amerasia Basin are similar to that of the Cretaceous. The persistent misfit of the present stress field and Early Cretaceous dyke swarms associated with the High Arctic Large Igneous Province indicates a short-lived transient change of the stress field at the time of dyke emplacement. Most rifts in the Amerasia Basin coincide with the stress field, suggesting that dyking and rifting were unrelated. We present new evidence for dykes and a graben structure of Early Cretaceous age on Bennett Island. 
The lithospheric structure and surface geology in many regions of the Arctic remain poorly defined. Consequently, many aspects of the tectonic evolution in this remote area are matter of significant debate. In this paper, we discuss the Phanerozoic tectonic evolution of the Arctic by comparing palaeo-stress indicators, such as dykes and rifts, with an estimate of the present-day stress field, the World Stress Map (WSM; Heidbach et al., 2010) and the calculated geopotential stress field. In the study area, the WSM is constructed almost entirely from earthquake focal mechanisms and borehole breakouts. Dyke swarms of Mesozoic and younger ages are distributed at various locations along the North American and Greenland Arctic margins, as well as the Barents Sea, Taimyr Peninsula and the New Siberian Islands. Large extensional rift systems of different ages are present along the Arctic shelfs as well as onshore. We compute the lithosphere-derived present-day stress

42 field by calculating the geopotential stress field that results from lateral pressure differences

43 in the lithosphere. The lithospheric density model used for calculating the geopotential energy (GPE) is a compilation of new data that includes sedimentary thickness, crustal thickness, dynamic topography (Lebedeva-Ivanova et al., 2015; 2016) and the lithosphereasthenosphere boundary (LAB) (Schaeffer et al., submitted; Schaeffer \& Lebedev, 2015b).

47 Comparison of spatially overlapping structures of varying age with the present-day stress

48 field (WSM) allows for large scale interpretation of stress field evolution and, therefore, insight into the tectonic evolution of the High Arctic.

\section{TECTONIC EVOLUTION}

52 The tectonic evolution of the High Arctic is complex and a number of aspects remain 53 incompletely understood, largely due to the lack of densely and homogeneously distributed

54 geological and geophysical constraints. While many components are a matter of significant

55 debate, there exist a number of major plate tectonic reconfigurations and tectono-thermal

56 events which are better understood and are briefly reviewed below. An overview of

57 geographic locations and major tectonic features is shown in Fig. 1. 
The landmasses currently within the High Arctic were involved in the assemblage of the supercontinent Pangaea. There were several orogenic events in the region constituting the Arctic part of Pangaea (present day $>60^{\circ} \mathrm{N}$ ). The Meso-to-Neoproterozoic GrenvilleSveconorwegian has been inferred to have affected parts of the Canadian Arctic, East Greenland, Svalbard, Franz Josef Land, Novaya Zemlya and Taimyr (Lorenz et al., 2012). During the Neoproterozoic to Cambrian Timanide Orogen, microcontinents and terranes were amalgamated along the northeastern Baltica margin (Gee \& Pease, 2004; Roberts \& Olovyanishnikov, 2004). The Timanide Orogen occurred prior to the Early Palaeozoic Caledonian Orogen that involved the collision of the continents of Baltica and Laurentia in the area of East Greenland, western Scandinavia, British Isles, northeast America, northern Germany and northwest Poland (Roberts, 2003; Gee et al., 2008; Leslie et al., 2008). The contemporaneous Ellesmerian Orogen may be the Arctic continuation of the Caledonian Orogen along the northern Laurentia margin in the Devonian (Piepjohn \& von Gosen, This volume; Gasser, 2013; Gee, 2015) during which multiple terranes (Chukotka, Chukchi, Arctic Alaska, etc.) may have accreted in a complex collisional system (Trettin, 1987; Beranek et al., 2010; Lawver et al., 2011; Lemieux et al., 2011; Anfinson et al., 2012). Divergence between the recently accreted Arctic terranes - now attached to Laurentia - and Siberia led to the collision between Siberia, northeast Baltica and the Kazakhstan plate forming the Urals in the late Carboniferous and Taimyr (Zhang et al., this volume; Otto \& Bailey, 1995; Cocks \& Torsvik, 2007; Pease \& Scott, 2009; Lawver et al., 2011; Zhang et al., 2013, 2015).

During the Permo-Triassic, Siberia and the Russian Arctic shelf were dominated by magmatic activity associated with the Siberian Traps Large Igneous Province, including the emplacement of extensive flood basalts and dyke swarms, and the formation of extensional rift basins (Reichow et al., 2002; Nikishin et al., 2010; Ivanov et al., 2013). The easternmost Russian Arctic terranes were assembled during the closure of the MongolOkhotsk Ocean in the late Jurassic (Zorin, 1999; Kravchinsky et al., 2002; Tomurtogoo et $a l .$, 2005). Novaya Zemlya is a fold belt formed in the Mesozoic (Curtis et al., this volume; Zhang et al., this volume).

In the middle and upper Jurassic, the closure of the Cache Creek Ocean and later, the subduction of the Farallon plate beneath western North America assembled further terranes and arcs to the Arctic Alaska terrane (Shephard et al., 2013). Extension along the Arctic 
Laurentian margin separated some of the assembled terranes from Laurentia culminating in the opening of the Amerasia Basin in the Early Cretaceous (Grantz et al., 1998; Lawver et al., 2011). This was partly contemporaneous to the emplacement of the High Arctic Large Igneous Province (HALIP), during which large volumes of magmatic products were emplaced as flood basalts and dykes, now mainly located in the Amerasia Basin, but also in the Canadian Arctic Archipelago, Svalbard and Franz Josef Land (Maher, 2001; Drachev \& Saunders, 2003; Buchan \& Ernst, 2006; Olesen et al., 2010; Grantz et al., 2011; Døssing et al., 2013b).

The Arctic Ocean is subdivided into the Amerasia Basin and the younger Eurasia Basin by the continental Lomonosov Ridge, which has crustal thicknesses (compare with Moho in Fig. 2, top right) of 25-30 km and extends from Greenland to the Siberian Shelf (Jokat et al., 1992; Grantz et al., 2001; Poselov et al., 2007). Whether the opening of the Amerasia Basin involved seafloor spreading, continental hyperextension, mantle exhumation or a combination of these is debated. This is mainly because of often unknown crustal affinity due to sparse or ambiguous geophysical and geological constraints, and complicated by the thick sedimentary and igneous cover over up to $50 \%$ of the Amerasia Basin and by later crustal modification (Gaina et al., 2011; Saltus et al., 2011; Gaina et al., 2013; Pease et al., 2014; Petrov et al., 2016). Samples from Alpha Ridge basalts are predominantly of late Cretaceous age (82-88 Ma), while the Mendeleev Ridge has been dated at $127 \mathrm{Ma}$ in the north and $260 \mathrm{Ma}$ in the south, close to Chukchi Borderland and the adjacent Canada Basin at 76-115 Ma (Van Wagoner et al., 1986; Jokat, 2003; Brumley, 2010; Morozov et al., 2012). Many models include oceanic crust in the most central part of the Canada Basin (Mosher et al., 2012; Petrov et al., 2016); others also interpret the Makarov Basin as oceanic (Lebedeva-Ivanova et al., 2011; Døssing et al., 2013b; Pease et al., 2014) or even the entire Amerasia Basin as oceanic (Alvey et al., 2008; Gaina et al., 2013), while a large part of the Amerasia Basin is also regarded to be of transitional or hyperextended continental crust (Lebedeva-Ivanova et al., 2006; Grantz et al., 2011; Pease et al., 2014; Li et al., 2016; Petrov et al., 2016). Consequently, different opening scenarios have been proposed in the debate regarding the origin of the Amerasia Basin (Dutro, 1981; Embry, 1990; Lane, 1997; Tessensohn et al., 2012), including but not limited to an anti-clockwise rotational opening during rifting of Alaska from the Canadian Arctic margin along a large- 
121 scale strike-slip fault proximal to the present day Lomonosov Ridge (Embry, 1991; Grantz 122 et al., 2011) or a transform fault along the Alpha-Mendeleev Ridge (Doré et al., 2015).

123 From the late Cretaceous to the late Palaeogene, the Labrador Sea and Baffin Bay 124 successively opened from south to north between Greenland and Canada (Chalmers \& 125 Pulvertaft, 2001). This caused SW-NE movement and counter clockwise rotation of 126 Greenland (Srivastava, 1985; Okulitch \& Trettin, 1991; Trettin, 1991a; Oakey \& Chalmers, 127 2012; Hosseinpour et al., 2013) and extension with associated alkaline magmatism in the 128 Lincoln Sea, North Greenland and Ellesmere Island (Trettin \& Parrish, 1987; Estrada et al., 129 2010; Tegner et al., 2011; Thorarinsson et al., 2012,2015). Seafloor spreading along the 130 North Atlantic ridge caused Greenland to move northward, terminated rifting and 131 volcanism in Labrador Sea (Thorarinsson et al., 2011; Døssing et al., 2013a) and resulted 132 in the Eurekan Orogen on Ellesmere Island and North Greenland in the Eocene 133 (Tessensohn \& Piepjohn, 2000; Tegner et al., 2011; Oakey \& Chalmers, 2012; Piepjohn et 134 al., 2016). Additional E-W compression caused by seafloor spreading along the Gakkel 135 Ridge during the opening of the Eurasia Basin (Brozena et al., 2003; Glebovsky et al., 136 2006; Engen et al., 2008; Døssing et al., 2013a; Gaina et al., 2015) may have enhanced 137 deformation in the Eurekan Orogen.

\section{LITHOSPHERIC STRUCTURE AND PRESSURE}

140 As a result of this tectono-magmatic evolution which included multiple compressional, extensional and igneous events, the High Arctic comprises several distinct tectonic units,

142 each of which are expressed in topography, sedimentary thickness, Moho and thickness of the lithosphere (the depth to the Lithosphere-Asthenosphere Boundary - the LAB). The spatial variation in such structures results in lateral variations in the integrated mass of the vertical columns driving pressure differences - the source of geopotential stresses. In this study we combine recent geophysical datasets for the whole High Arctic region, including a newly compiled crustal model (Lebedeva-Ivanova et al., 2015, 2016) and LAB depth model (Schaeffer et al., submitted; Schaeffer \& Lebedev, 2015b). Together, these form the basis for our density model used to calculate geopotential energy and, ultimately, the corresponding geopotential stress field. 
The crustal model of Lebedeva-Ivanova et al. (2016) describes observed topography and bathymetry (Fig. 1, left), thicknesses and densities for a sedimentary and a crustal layer from $68-90^{\circ} \mathrm{N}$ (Fig. 2). Modifications were made at the boundaries in order to incorporate it into the global CRUST1.0 model (Laske et al., 2013). The Arctic model of LebedevaIvanova et al. (2016) shows sedimentary basins (Fig. 2, top left) with depths of $10 \mathrm{~km}$ and more in the southern Canada Basin/Beaufort-MacKenzie Sea (Stephenson et al., 1994b; Sippel et al., 2013), Chukchi Basin (Drachev, 2011) and in the eastern Barents Sea (Drachev et al., 2010; Minakov et al., 2012; Klitzke et al., 2015). Other areas with locally substantial sedimentary thickness $>5 \mathrm{~km}$ are observed in Baffin Bay (Funck et al., 2012; Suckro et al., 2012; Altenbernd et al., 2015), the Sverdrup Basin (Embry, 1991; Embry \& Beauchamp, 2008; Oakey \& Stephenson, 2008; Schiffer et al., 2016), the Lincoln Sea (Jackson et al., 2010; Funck et al., 2011), the western Barents Sea (Ritzmann et al., 2007; Klitzke et al., 2015), the Kara Sea (Drachev et al., 2010) and the Russian Arctic shelf (Drachev \& Shkarubo, this volume; Drachev, 2011).

The Amerasia Basin is one of the most debated features of the Arctic Ocean, with sections of possibly oceanic crust (e.g. the central Canada Basin and the Makarov Basin), others of hyperextended or intruded continental crust, while a large part is covered by a sedimentary cover and flood basalts of the Alpha-Mendeleev Ridge complex (Lebedeva-Ivanova et al., 2006, 2011; Jackson et al., 2010; Funck et al., 2011; Mosher et al., 2012; Li et al., 2016).

Chukchi Borderland and the De Long Massif are continental terranes, separated and broken apart during the opening of the Amerasia Basin, with crustal thicknesses of up to $35 \mathrm{~km}$ subdividing other smaller basins. While the crustal affinities of the Amerasia Basin are poorly constrained, the younger Eurasia Basin is clearly of oceanic origin and shows less complexity, at least from a kinematic point of view (Brozena et al., 2003; Engen et al., 2008). The continental shelf is generally much wider along the Russian (Moho at 35-40 km depth) and Barents Sea margins (Moho at 30-35 km depth) than along North America and Greenland.

The Arctic Ocean is surrounded by a number of orogenic belts. In the East Greenland Caledonides the Moho is estimated at up to 45-50 km depth (Artemieva \& Thybo, 2013; Schiffer et al., 2015a). Similar depths have been estimated for the Scandinavian Caledonides (Grad et al., 2009; Ebbing et al., 2012; Artemieva \& Thybo, 2013) and the Ellesmerian/Eurekan Orogen. A substantially shallower Moho has been estimated in the 
184 Sverdrup Basin at 30-35 km (Schiffer \& Stephenson, this volume; Stephenson et al., this

185 volume; Oakey \& Stephenson, 2008; Schiffer et al., 2016). Beneath Svalbard, Novaya

186 Zemlya and Taimyr, the Moho is estimated at up to $40 \mathrm{~km}$ depth or more (Faleide et al.,

187 this volume; Ritzmann et al., 2007; Ivanova et al., 2011; Klitzke et al., 2015). Moho

188 beneath the stable cores of the surrounding continents is at depths of 35-45 km (Fig. 2).

189 Sub-lithospheric pressure

190

191

192

193

194

195

196

197

198

199

200

201

202

203

204

205

206

207

208

209

210

211

212

213

214

In the modelling, lateral sub-lithospheric pressure variations which could be produced by mantle convection patterns or thermal or compositional anomalies in the sub-lithospheric mantle were permitted. Such a pressure anomaly gives rise to dynamic topography. The Arctic crustal model from Lebedeva-Ivanova et al. (2016) provides an estimate of dynamic topography. The model was translated into a sub-lithospheric pressure anomaly that is required to produce the resulting dynamic uplift or subsidence. This pressure anomaly was smoothened to a harmonic degree of 36 (Fig. 2, bottom right) and integrated with a global sub-lithospheric pressure anomaly from Schiffer \& Nielsen (2016), which may result in discrepancies at the edges of the study area at c. $70^{\circ} \mathrm{N}$ between the used and the original data sets.

The pressure anomaly and corresponding dynamic topography (Fig. 2, bottom right) is of long wavelength and shows a clear maximum of $\sim 10 \mathrm{MPa}$ (corresponding to at most $400 \mathrm{~m}$ uplift) in Northeast Greenland and Jan Mayen, approaching the Iceland melt anomaly. Slightly lower positive pressure anomalies of 0 to $5 \mathrm{MPa}(0 \mathrm{~m}$ to $150 \mathrm{~m}$ uplift $)$ are present in Greenland and Arctic Canada, while a low amplitude negative anomaly of -6 to $-2 \mathrm{MPa}$ (approx. $350 \mathrm{~m}$ to $0 \mathrm{~m}$ subsidence) is located along the Russian Arctic shelf. We note that the North Pole region demonstrates no anomalous mantle pressure.

\section{Mantle lithosphere}

The Earth's lithosphere plays a key role in the dynamic processes associated with plate tectonics, as the base of the lithosphere is a first order boundary separating the actively connecting, weak asthenosphere from the overlying rigid lithospheric plate. There are, however, a number of different ways to define the base of the strong lithospheric lid, including mechanical, compositional, rheological, thermal, and anisotropic interpretations (Artemieva, 2009; Eaton et al., 2009; Fischer et al., 2010). We use the LAB depth model (Fig. 2, bottom left) derived from a recent multimode (Lebedev \& Van Der Hilst, 2008; 
215 Schaeffer \& Lebedev, 2013; Schaeffer \& Lebedev, 2015a) surface waveform tomography

216 model of the Arctic, AMISvArc, described in detail in Schaeffer et al. (submitted, 2015b).

217 The authors utilised a common proxy for the LAB in surface-wave based studies, namely

218 the depth at which the velocity anomalies dropped below the $+2 \%$ fast velocity contour

219 with respect to the 1D mantle reference model AK135 (Kennett et al., 1995). This estimate

220 is in many ways analogous to a thermal estimate for the LAB, as the seismic velocities are

221 dominantly sensitive to variations in temperature. This $+2 \%$ fast criterion is optimal for

222 identifying the depth to the LAB beneath stable continental regions; in regions with

223 elevated temperatures, such as continental areas undergoing active deformation or beneath

224 all but the oldest parts of oceanic plates, the $+2 \%$ fast criterion is not satisfied because the

225 observed velocities are less than the reference model (i.e., negative velocity anomalies).

226 The calculation for the geopotential stress field requires a continuous LAB depth model, so

227 we combine the LAB model from (Schaeffer et al., submitted; Schaeffer \& Lebedev,

228 2015b) with other LAB constraints across the High Arctic. For example, in the Eastern

229 Russian Arctic, other models indicate a LAB depth of 50-100 km throughout the region

230 (Conrad \& Lithgow-Bertelloni, 2006; Artemieva, 2009); therefore we assigned a constant

231 thickness of $75 \mathrm{~km}$ across this region. In the oceanic domain, apart from the thicker

232 lithosphere underlying the Canada Basin, we utilise a plate-age (Müller et al., 2008) based

233 estimate for lithospheric thickness using a standard "half space" ocean age evolution model

234 (Stein \& Stein, 1992) where applicable.

235 The original LAB model, computed on a triangular grid of tessellated knots (Wang \&

236 Dahlen, 1995) with an average spacing of $\sim 280 \mathrm{~km}$, was expanded onto spherical

237 harmonics up to a degree of 64. The LAB depth model (Fig. 2, bottom left) roughly follows

238 the standard ocean age dependent depth model with $<50 \mathrm{~km}$ at Mid Ocean Ridges and

239 increasing to $\sim 120 \mathrm{~km}$ at the continent-ocean boundaries. In Baffin Bay, the LAB is at $\sim 120$

$240 \mathrm{~km}$ depth, corresponding to old oceanic lithosphere at the extinct spreading ridge. The

241 Amerasia Basin also has relatively thin lithosphere at $\sim 75 \mathrm{~km}$ depth north of Ellesmere

242 Island and North Greenland, in the Canada Basin and along the Mendeleev Ridge, $\sim 100 \mathrm{~km}$

243 elsewhere along the Alpha-Mendeleev Ridge and up to $\sim 150 \mathrm{~km}$ at the margins of the

244 Canada Basin. The continent-ocean boundaries (COB; Fig. 2, thick black lines; stippled

245 where alleged or extinct, Müller et al. 2008) are clearly defined by steep LAB depth

246 gradients from thinner oceanic to thicker continental lithosphere in most places. Exceptions 
are observed along the eastern Russian shelf, including the Chukchi plateau and the De Long Massif, where thin lithosphere continues far inside the continental interior. This steep gradient is also lacking in the Canada Basin, where the lithosphere is up to $200 \mathrm{~km}$ thick at the edges of the basin - thicker than typical oceanic lithosphere - and gradually thins to a minimum of $\sim 90 \mathrm{~km}$ in the centre.

The north-westernmost part of Svalbard and the possible continental extension to the north show extremely thin lithosphere, atypical of continents, and was also observed by previous workers (Klitzke et al., 2015). The concluding observation is that the presumed boundaries (Müller et al., 2008) between the continents and the Amerasia Basin (Fig. 2, thin black lines are a COB interpretation from Pease et al., 2014) do not always clearly coincide with a change in LAB depth. Thin lithosphere is sometimes observed outside the proposed COB and thicker lithosphere is often observed within the basin. This shows that the position of the COB is either not well-known (or is differently defined), or the definition fails in some regions of the Arctic Ocean. Greenland, southern Ellesmere Island, Arctic Canada (south of the Sverdrup Basin), the Barents Sea, Novaya Zemlya, Kara Sea, Taimyr and western Siberia have very thick lithosphere with an LAB at $>225 \mathrm{~km}$ depth, but with significant internal variation.

\section{GEOPOTENTIAL STRESS FIELD}

Our methods follow Schiffer \& Nielsen (2016) and Nielsen et al. (2014) and only the most important elements of these are summarised here. The geopotential energy (GPE) is the integral over the vertical column of a lithostatic pressure anomaly, defined as:

$$
G P E=\int_{-H}^{L}(L-z) \Delta \rho g d z,(1)
$$

where $L$ is the depth up to which density variations are incorporated, $H$ the topographic elevation, $\Delta \rho$ the vertical density anomaly with respect to a reference lithosphere and $g$ is the gravitational acceleration.

The density column of the mantle lithosphere was defined by thermal expansion of peridotite along a conductive geotherm using a reference thermal expansion coefficient of $\alpha=2.4 \cdot 10^{-5} \mathrm{~K}^{-1}$ and a reference density of $3350 \mathrm{~kg} \cdot \mathrm{m}^{-3}$. The geotherm was defined by a surface temperature of $0{ }^{\circ} \mathrm{C}$, a temperature at the LAB by the adiabatic mantle geotherm of 
$[\partial \mathrm{T} / \partial \mathrm{z}]=0.6^{\circ} \mathrm{C} / \mathrm{km}$ (McKenzie \& Bickle, 1988), a reference potential temperature of 1315 ${ }^{\circ} \mathrm{C}$ (McKenzie et al., 2005), and representative thermal conductivities and heat production rates for sediments, crust and lithosphere (Schiffer \& Nielsen, 2016). The expansion coefficient and thermal conductivity are regarded as temperature dependent (Bouhifd et al., 1996; McKenzie et al., 2005). Horizontal gradients of GPE are a source of deviatoric stress in the lithosphere. To calculate these stresses, a thin sheet approximation of the lithosphere (Bird \& Piper, 1980; England \& McKenzie, 1982; England \& Houseman, 1986) was assumed. Horizontal tractions at the base of the lithosphere were neglected, since mantle flow patterns and mechanical coupling between the asthenosphere and lithosphere are poorly constrained and generally much less important than vertical stress.

Given this, the equations of equilibrium of stresses read:

$$
\left(\begin{array}{l}
\frac{\partial \bar{\tau}_{x x}}{\partial x}+\frac{\partial \bar{\tau}_{x y}}{\partial y}=-\frac{1}{L}\left(\frac{\partial G P E}{\partial x}+L \frac{\partial \bar{\tau}_{z z}}{\partial x}\right) \\
\frac{\partial \bar{\tau}_{y x}}{\partial x}+\frac{\partial \bar{\tau}_{y y}}{\partial y}=-\frac{1}{L}\left(\frac{\partial G P E}{\partial y}+L \frac{\partial \bar{\tau}_{z z}}{\partial y}\right)
\end{array}\right)
$$

Here, $x$ and $y$ are local horizontal coordinates, $\overline{\boldsymbol{\tau}}$ represents depth integrated deviatoric stresses, $\overline{\boldsymbol{\tau}}_{x x}, \overline{\boldsymbol{\tau}}_{y y}, \overline{\boldsymbol{\tau}}_{x y}$ are horizontal deviatoric stresses, $L$ is the reference depth and $\overline{\boldsymbol{\tau}}_{z z}$ is a sub-lithospheric pressure anomaly acting vertically at the base of the lithosphere (radial tractions), which was derived from the dynamic topography grid.

The final equations of equilibrium of stresses (Eq. 2) were solved using the Finite Element Method (FEM) in the following way (Zienkiewicz, 1977, Chap. 16): the spherical Earth is represented by a dense grid of flat, thick, triangles with an elastic rheology. The material parameters of each element comprise Young's modulus $(E)$, Poisson's ratio $(v)$ and a uniform thickness (L). Interested readers are referred to Schiffer \& Nielsen (2016) for further information.

The elastic shell approximates the strength carrying layer of the Earth's lithosphere, which supports stresses. Lateral thickness variations of this layer cause stress refraction, which influence stress directions, but because of the smooth thickness variations in the present model such refraction effects are small. The primary influence of variations in thickness of the strength carrying layer are the magnitude of the stress flux, which does not influence the orientation of the stress field. 
We follow common approaches to calculate the geopotential energy and the corresponding stress field and use a reference depth of $\mathrm{L}=100 \mathrm{~km}$, corresponding to the upper lithospheric structure as the main stress-carrying layer (Flesch et al., 2001; Ghosh et al., 2008). Additionally, a reference depth of $50 \mathrm{~km}$ - corresponding to mostly crustal structure - is used to investigate differences between shallow and deep sources of geopotential stress. A comparison is shown in figure 4.

We use a spatially averaged representation of the WSM. A location is attributed a stress orientation if at least three high quality measurements (quality A, B and C of the WSM) are within a radius of up to $250 \mathrm{~km}$, while smaller distances above $50 \mathrm{~km}$ are preferred. Again, details are described in Schiffer \& Nielsen (2016). The resulting GPE, stress field and a comparison with the WSM are shown in Figure 3 (top panel).

\section{DYKES AND EXTENSIONAL STRUCTURES IN THE HIGH ARCTIC}

Palaeo-stress indicators can be found across the High Arctic (Fig. 3, bottom panels). Dykes are usually emplaced parallel to the maximum horizontal compressive stress. Large systems of extensional basins may also be oriented along the most compressive horizontal stress direction, although these may be influenced by existing and inherited rift structures. In Figure 3 (bottom panel) we show Phanerozoic dykes and rift systems in the High Arctic of known age. Figure 1 shows the location of these basins.

\section{Ordovician to Carboniferous}

The oldest of the Phanerozoic rift basins in the Arctic include the Pechora Basin (Klimenko et al., 2011) and the North Kara Basin (Stoupakova et al., 2011), which both started extending in the Ordovician (Nikishin et al., 1996; Gee \& Pease, 2004; Drachev, 2016). The Pechora Basin experienced a second phase of extension in the Devonian. The North Kara Basin has a predominant W-E fault orientation, whereas the Pechora Basin has a NNW-SSE orientation. Rifting in the East Barents megabasin started in the late Devonian with a SW-NE oriented rift axis in the southwestern part and W-E in the northeastern part (Nikishin et al., 1996; Drachev et al., 2010; Drachev, 2016). Normal fault systems in the western Barents Sea formed in the Carboniferous and are generally NW-SE trending (Gudlaugsson et al., 1998; Faleide et al., 2008; Henriksen et al., 2011). The Sverdrup Basin formed initially as a result of lithospheric relaxation of the Ellesmerian Orogen, then as an 
active rift in the Carboniferous to Permian (Embry, 1991) and finally as a consequence of thermal subsidence (Stephenson et al., 1994a). The Wandel Sea Basin in Northeast

Greenland opened at a similar time during the Carboniferous and Permian and is related to rifting between Greenland and Scandinavia (Håkansson \& Stemmerik, 1989; Stemmerik et al., 1998).

\section{Permo-Triassic}

Siberian Trap magmatism is one of the largest magmatic events on Earth, stretching from around $60-120^{\circ} \mathrm{E}$ and $50-75^{\circ} \mathrm{N}$ and dated at approximately $251 \mathrm{Ma}$ (Reichow et al., 2002, 2009, Burgess \& Bowring, 2015). Large scale N-S trending extensional fault systems in the West Siberian Basin developed contemporaneously, indicating the regional-scale orientation of the stress field during this time (Reichow et al., 2002). NNW-SSE trending dykes and associated normal faults on Bel'Kov Island (westernmost New Siberian Island, Fig. 1) also date to c. $251 \mathrm{Ma}$ and have been linked with the Siberian Trap magmatic event (Kuzmichev \& Pease, 2007; Danukalova et al., 2014). Dyke swarms on Taimyr have been dated to slightly older (280 Ma; Pease \& Vernikovsky (2000)) and slightly younger (220$250 \mathrm{Ma}$, Walderhaug et al. (2005)). Reichow et al. (2016) recently revised this work and presented ages of intrusions on the Taimyr Peninsula coinciding with the Siberian Traps. Their NE-SW and ENE-WSW orientations are very different from the N-S extensional rift systems in the area of the Siberian Traps. To the north of the East Siberian Basin, the Yenisei-Khatanga Trough opened along a very similar axis as the Taimyr dyke swarm (Drachev et al., 2010).

\section{Early Cretaceous}

In the Early Cretaceous, voluminous magmatism occurred in many parts of the High Arctic, forming the HALIP. Part of this is a large dyke swarm emplaced into the Amerasia Basin, the Canadian and Greenland Arctic shelves and borderlands, Svalbard and Franz Josef Land (Drachev \& Saunders, 2003; Buchan \& Ernst, 2006). Dykes, sills and lavas are abundant in the Canadian Arctic Archipelago and cover a long time span but with a main phase of basaltic volcanism at c. 127-115 Ma. On Ellef Ringnes Island a major dyke and sill swarm is dated at 127-121 Ma and mainly strikes NE-SW (Evenchick et al., 2015). On Axel Heiberg Island the Early Cretaceous dyke swarm mainly strikes N-S (Buchan \& Ernst, 2006), has been dated at $123 \mathrm{Ma}$ (Pease \& Nobre Silva, 2015), and can be directly linked 
to magnetic signatures that extend into the offshore domain (Anudu et al., 2016). On Ellesmere Island HALIP volcanism and dykes ranges from c. 122 to $74 \mathrm{Ma}$ (Estrada \& Henjes-Kunst, 2013). Dykes and sills are also outcropping on Svalbard (Senger et al., 2014) and can also be extended offshore (Olesen et al., 2010) and into the Barents Sea (Polteau et al., 2016). Similarly, a major dyke swarm has been mapped on Franz Josef Land (FJL) (Dibner, 1998) with peak ages at 138-110 Ma and can also be extended offshore using aeromagnetic data (Glebovsky et al., 2006; Minakov et al., 2012; Døssing et al., 2013b). The dykes in the European part of the Arctic have been dated at 130-110 Ma (Corfu et al., 2013). Moreover, Døssing et al. (2013b) used aeromagnetic data to interpret a large offshore dyke swarm between (and partly within) Alpha Ridge, Lomonosov Ridge, Ellesmere Island and Makarov Basin; its age is unconstrained, but given a clear spatial relation of this dyke swarm with the FJL dykes in palaeogeographic reconstructions, an early Cretaceous age is very likely. Predominant orientations of other dyke swarms are NNE-SSW in the western Sverdrup Basin and the Alpha Ridge, N-S to NW-SE along the northern coastline of Ellesmere Island and Axel Heiberg Island, NW-SE on Franz Josef Land and NNW-SSE in the Barents Sea, and roughly N-S on and around Svalbard. In some plate tectonic reconstructions, these are interpreted to form a radiating dyke swarm (Buchan \& Ernst, 2006; Døssing et al., 2013b).

The Amerasia Basin opened during the Early Cretaceous (but this is debated) and the rift axes are N-S to NNW-SSE oriented (Nikishin, 2014; Petrov et al., 2016). The Canada Basin is by some authors interpreted to be partly formed by oceanic spreading (e.g., Mosher et al., 2012; Pease et al., 2014; Petrov et al., 2016). Banks Basin and the Sverdrup Rim (see Fig. 1), both oriented parallel to the shelf edge, developed as a consequence of rifting and the subsequent opening of the Amerasia Basin (Embry \& Dixon, 1990).

In Fig. 5 we present further evidence for the orientation of dykes and a graben structure on Bennett Island, part of the De Long Islands at $\sim 150^{\circ} \mathrm{E}$ on the Russian Arctic Shelf (Vol'nov \& Sorokov, 1961). Bennett Island is composed of lower Palaeozoic sediments overlain by flood basalts that have been dated at 119-112 Ma and interpreted as part of the HALIP (Drachev \& Saunders, 2003; Tegner \& Pease, 2014). Two dykes at the western end of the island (Cape Emma) strike approximately NE-SW and are interpreted as coeval with the flood basalt event (Fig. 5 a, b). The south-eastern end of the island displays a graben structure (Fig. 5 c) in a similar orientation and that accommodated the basaltic eruptions. 
We interpret these structures on Bennett Island as indicative of NW-SE extension in the Early Cretaceous.

\section{Late Cretaceous}

Three suites of late Cretaceous alkaline dykes are located on the North Greenland margin. One population is E-W oriented, another N-S and the third NW-SE, and all have similar ages (81-85 Ma) (Buchan \& Ernst, 2006; Thórarinsson et al., 2015). The N-S orientation of one dyke population appears to be parallel to the rift axis of the Eurasia Basin, while the NW-SE orientation of the other population may relate to mapped extensional structures along the Alpha and Lomonosov Ridges (Døssing et al., 2013a; Thórarinsson et al., 2015).

Pervasive, roughly N-S striking extensional fault systems are distributed over large parts of the Russian Arctic shelf from approximately $150^{\circ} \mathrm{W}$ to $120^{\circ} \mathrm{E}$. The Laptev Sea Basin defines the westernmost set of normal faults within the Laptev rift system, and its easternmost part is represented by the New Siberian Basin located north of the New Siberian Islands. The Laptev Sea Basin reflects continental rifting along the landward extension of the present-day Gakkel Ridge during the late Cretaceous and early Eocene (Drachev \& Shkarubo, this volume; Engen et al., 2003; Drachev, 2011). Continental breakup occurred along the Gakkel Ridge at c. $56 \mathrm{Ma}$, but might have failed to propagate into the Laptev Sea (Franke et al., 2001; Drachev et al., 2003; Van Wijk \& Blackman, 2005; Franke \& Hinz, 2009) and the spreading ridge was probably aborted in the mid Cenozoic. It was rejuvenated during the middle Miocene through middle Pleistocene (Drachev, 2011).

\section{Cenozoic}

During the Eocene, seafloor spreading started in the Northeast Atlantic and in the Eurasia Basin. The present-day passive margins away from transform margins may represent the general direction of the stress field at the time of break-up. Therefore, we use the passive margins as weak indicators of palaeo-stress orientations, even though it is very possible that inheritance plays an important role in the development of rifts. In the present-day Northeast Atlantic, Pangaea broke apart at approximately $53 \mathrm{Ma}$, while at approximately 25 Ma a Northeast Atlantic ridge jump caused the separation of Jan Mayen (Mosar et al., 2002; Nielsen et al., 2007; Tegner et al., 2008; Gernigon et al., 2015). The Eurasia Basin opened simultaneously as an elongated ocean basin along the future ultra-slow spreading Gakkel Ridge (Brozena et al., 2003; Gaina et al., 2015). The Fram Strait region developed 
from the De Geer transform fault, connecting the Arctic and the North Atlantic since the early Eocene (Engen et al., 2008; Doré et al., 2015). It displays a complex system of transform faults, fracture zones and oblique spreading ridges oriented nearly perpendicular to the North Atlantic and Gakkel Ridges, and seafloor spreading has been active since the Miocene (Engen et al., 2008; Doré et al., 2015). This complexity compromises a detailed interpretation of the palaeo-stress field. The East Siberian Sea is much less studied compared to the Laptev Sea, but overall is considered to have experienced much less extension. It subsided post-Late Cretaceous and during the initial phases of seafloor spreading along the Gakkel Ridge from the Eocene, the East Siberian Basin is suggested to have formed through large-scale extensional/transtensional deformation, which terminated in the Middle-Late Miocene (Drachev \& Shkarubo, this volume; Franke et al., 2004; Franke \& Hinz, 2009; Drachev, 2011, 2016).

\section{RESULTS}

\section{Geopotential stress field}

We calculated the GPE (Fig. 3, top left) as one source of lithospheric stresses in the High Arctic. The GPE distribution identifies distinct provinces. The cratons exhibit very low GPE values, which is the result of deep lithospheric keels, low topography and the presence of sedimentary basins. Conversely, a high GPE is caused by high topography (e.g. East Greenland, Ellesmere Island, as well as the Lomonosov, Alpha, Gakkel and Mid Atlantic Ridges), thin mantle lithosphere (ocean basins, parts of the Amerasia Basin, Bering Strait region at $\sim 180^{\circ} \mathrm{E} / \mathrm{W}$ ) and the lack of a sedimentary cover.

The geopotential stress field is used as an approximation of the present-day lithospheric stress field (Fig. 3, upper panel). The stresses are aligned with the active Gakkel Ridge and the Mid-Atlantic Ridge. This also applies for the extinct spreading ridge in northern Baffin Bay. However, north of Jan Mayen, along the Mohns and Knipovich Ridges where seafloor spreading occurs along a highly complex and oblique spreading ridge with a strong translational component, the calculated and observed stress orientation deviates from the ridge axis. The stress field appears uniform throughout the oceanic Eurasia Basin. The same is observed in the Amerasia Basin, where the equally uniform stress field is slightly 
rotated anticlockwise by $10-20^{\circ}$ relative to the Eurasia Basin. The Lomonosov Ridge appears to demarcate the boundary between these two stress regimes.

The stress orientation changes from N-S along the East Greenland coastline to a more NWNE direction in the interior of the continent and to N-S in North Greenland and Ellesmere Island. In the eastern part of the Canadian Arctic Archipelago, the principle compressive stresses are coast-parallel, before changing to a $\mathrm{N}-\mathrm{S}$ orientation at about $130^{\circ} \mathrm{W}$. This trend is observed along the entire shelf to $\sim 130^{\circ} \mathrm{E}$, with slight complexity at $150^{\circ} \mathrm{E}$. At $130^{\circ} \mathrm{E}$, the stress field changes to a NE-SW orientation, pointing towards the GPE low and corresponding to thick cratonic lithosphere. Along the western Russian Arctic shelf, the stress field changes gradually anticlockwise from the initial NE-SW direction at Taimyr to a W-E orientation across almost the entire western Barents Sea.

\section{Comparison with the World Stress Map}

The World Stress Map (WSM) is a global compilation of stress field observations, including several in-situ measurements and the analysis of focal mechanisms from earthquakes (Heidbach et al., 2010). Due to the remote location of the study region, stress measurements are mostly based on the calculation of focal mechanisms where available, especially in offshore areas such as along the Gakkel Ridge, North Atlantic Ridge and in Baffin Bay, but also in East Siberia. We note that single focal mechanisms do contribute to the WSM elsewhere. Borehole breakouts are most abundant in the western Barents Sea and in the Alaska and Canadian polar margins. A small subset of drill induced fracturing data are also included in the western Barents Sea. Comparison with the WSM shows that the computed stresses in most regions are in fairly close agreement, with some exceptions (Fig. 3 , top right).

Misfits can have several causes: (a) the assumed lithospheric density structure for the area may be incorrect and model errors or coarse resolution can produce inaccuracies within the GPE model; (b) the sub-lithospheric pressure anomaly and resulting dynamic topography may have errors which propagate to the GPE model; (c) intraplate seismicity in the High Arctic is sparse and weak, thus high quality observations of the stress directions may be limited (cf. WSM) and can result in poor observation quality. We also acknowledge differences due to different methods used to estimate the stress field orientation. Borehole breakouts, drill fracturing, etc., which may be sensitive to different depth ranges, e.g. focal 
mechanisms are more representative of crustal to lithospheric scale stress, whereas borehole

492 breakouts may only account for shallower (few $\mathrm{km}$ ) depths. Finally, (d) there might be far-

493 field tectonic forces acting on the lithospheric stress field today, e.g. from distant

494 subduction and collision zones.

495 We identify three regions of substantial misfit between observed stresses (WSM) and the 496 computed geopotential stress field (Fig. 3 upper right, Fig. 4). In the western Barents Sea

497 (between Svalbard and Norway) the stress field undergoes a radical change from a direction 498 parallel to the North Atlantic passive margin to a direction almost perpendicular further 499 inside the Barents Sea. This deviation in the stress field is possibly related to the observed 500 rapid change in LAB depth from $>200 \mathrm{~km}$ in the east to $\sim 100 \mathrm{~km}$ in the oceanic domain in 501 the west. The WSM, however, shows a corresponding change in stress orientation much 502 further within the continental interior.

503 The East Siberian margin at $\sim 120-130^{\circ} \mathrm{E}$ shows a similar misfit at the edge of a rather 504 steep LAB depth gradient ( $225 \mathrm{~km}$ in the interior of the continent to $<150 \mathrm{~km}$ to the north 505 and east). A different LAB depth architecture in this region, or any of the above mentioned 506 possible errors might explain this misfit.

507 Another area of substantial misfit is observed in the Beaufort Sea, between the western 508 Canadian Arctic Islands and the Brooks Range at $\sim 130-140^{\circ} \mathrm{W}$. The WSM shows E-W 509 oriented stress, whereas the computed stress field indicates a continuous N-S orientation. A 510 steeper E-W LAB depth gradient could produce such a stress field.

511 An interesting observation is that two of these regions are spatially co-located with regions 512 where borehole breakout data are the dominant contribution to the WSM (western Barents 513 Sea and Beaufort Sea). This may suggest that in these regions the WSM is dominantly 514 sensitive to shallower structures where stress orientations are different from those in the 515 deeper crust and lithosphere.

516 As indicated, the areas of high misfit are typically localised at steep edges of thick 517 lithosphere. In a previous study, an LAB model was iteratively adjusted to fit the observed 518 stress field (cf. Schiffer \& Nielsen, 2016). The final model showed much smoother LAB 519 depth gradients and a correspondingly better fit with the WSM. Exploring what effect 520 absolute LAB depth and LAB gradient have on the GPE are beyond the scope of this paper, 521 but will be examined in detail in subsequent work. For some regions, a lack of data limits 
522 the WSM, and this is especially true for the predominant use of focal mechanisms and the

523 lack of independent stress field measurements.

524 Excluding the regions of large misfit, the computed and observed stress directions match

525 very closely and are sufficient to argue that the geopotential stress field is a robust

526 representation. It is important to note that the modelling of the geopotential stress field

527 presented in this study covers the entire High Arctic region, whereas the WSM is limited to

528 areas of active seismicity (i.e., seafloor spreading ridges) and some limited areas of

529 intraplate seismicity and boreholes.

530 Figure 4 shows a comparison between the calculated shallow (50 km) and deep (100 km)

531 geopotential stress field, together with the smoothed WSM. As previously observed, the

532 geopotential stress field for both depths as well as the WSM closely match in most regions.

533 The deviation between both stress fields is observed dominantly along passive margins,

534 such as the margin of Chukchi to the Canada Basin, in the Laptev Sea and East Siberian

535 Sea, along the Canadian polar margin and the Barents Sea Atlantic margin and Amerasia

536 Basin margin close to Franz Josef Land. Across the entire High Arctic, the shallow

537 geopotential stress field fits better $\left(24.27^{\circ}\right.$ azimuthal misfit) than the deep geopotential

538 stress field $\left(27.66^{\circ}\right.$ misfit $)$; this likely reflects the generally shallower sensitivity of the

539 WSM. In the following we choose to represent the present-day lithospheric stress field with

540 the geopotential stress field utilising density structure to a depth of $100 \mathrm{~km}$, which we

541 interpret to be more representative for lithosphere scale tectonic structure.

542

543 Comparison with dyke swarms and rifts

544 The geopotential stress field (Fig. 3) can be compared with dyke swarms and extensional

545 basins which act as palaeo-stress markers. Figure 6 shows the Phanerozoic extensional rift

546 systems and dyke swarms of different ages in the High Arctic described above and

547 separately shown in Fig. 3 (bottom panel) in comparison with the computed geopotential

548 stress field (black lines). This allows for a direct comparison and evaluation of regions of

549 better or worse fit.

550 The oldest observed rift systems in the western and eastern Barents Sea (Fig. 6, dark blue)

551 show poor agreement with the present-day stress field and, hence, we suggest that the 
552 Ordovician to Carboniferous stress field associated with these rift systems has been

553 subsequently modified. Furthermore, the axis of the Sverdrup Basin is almost perpendicular

554 to the computed geopotential stress field. Indeed, both regions have experienced a complex

555 tectonic evolution, with multiple reconfigurations of the stress regime, including multiple

556 extensional and orogenic events, such as the Cenozoic Eurekan Orogeny (Piepjohn et al.,

557 2016).

558 Permo-Triassic geological structures show generally good alignment with the contemporary 559 geopotential stress directions in the Siberian Trap region and Taimyr (Fig. 6, light blue). It 560 appears that the stress field has not changed significantly in these regions of good fit, even 561 though late Triassic folding has been reported from the Taimyr Peninsula (Inger et al.,

562 1999; Torsvik \& Andersen, 2002).

563 None of the Early Cretaceous dyke swarms associated with the HALIP show a clear

564 alignment with the geopotential stress field today (Fig. 6 green). In contrast, in the 565 Amerasia Basin (Nikishin, 2014) and Banks Basin (Trettin, 1991b) in the Canadian Arctic

566 show relatively good agreement. This indicates that rifting and dyking occurred under

567 different stress regimes during the Early Cretaceous period, which is plausible considering

568 the debated age of the opening of the Amerasia Basin. This may indicate that the stress

569 field at the time of the emplacement of these intrusions was markedly different and thus

570 may represent a potentially short-lived departure from the ambient stress field. The

571 radiating pattern of the HALIP dykes have been interpreted to reflect a mantle plume

572 (Buchan \& Ernst, 2006). We suggest that the deviation in the orientation of the Cretaceous

573 dyke swarms from the present stress field is consistent with a relatively short lived sub-

574 lithospheric pressure, though we are unable to draw any diagnostic conclusions about the

575 geodynamic mechanism behind this observation.

576 Nearly all Late Cretaceous extensional structures and dykes are in alignment with the

577 present-day stress field, including North and Northeast Greenland and the adjacent Alpha

578 Ridge. The mapped normal faults in the Laptev Sea Rift experienced rifting from the Late

579 Cretaceous to early Cenozoic and again in late Neogene. The mapped rift systems are

580 generally in very good alignment with the geopotential stress field. A set of Permo-Triassic

581 dykes on Bel'Kov Island in this area are also emplaced in the same direction, but these

582 dykes are suggested to be rotated from a position as a northern continuation of the Uralides, 
583 close to Severnaya Zemlya (Pease, 2011). The passive margins of Baffin Bay, the North

584 Atlantic and the Eurasia Basin may represent the palaeo-stress field at the time of

585 continental break-up from Palaeocene and Eocene (Fig. 6, red) and are also aligned with the

586 present/day stress field. Break-up in the Fram Strait and Knipovich Ridge region, however,

587 do not show a coincident orientation.

588 Cenozoic extensional structures are distributed over a large part of the eastern Russian

589 Arctic margin and largely coincide with the computed geopotential stress field (Fig. 6,

590 magenta). As discussed above, the Laptev Sea Rift has experienced extension in the same

591 orientation since the Late Cretaceous, thus the stress field in this region is assumed not to

592 have changed significantly, despite the onset of seafloor spreading along the Gakkel Ridge

593 and the formation of a fracture zone along the Laptev shelf area (Drachev et al., 2003). The

594 Cenozoic rift system in the East Siberian Sea supposedly formed during large-scale

595 extensional/transtensional Eocene deformation, whereas only relatively passive subsidence

596 has been reported since the Late Cretaceous (Drachev \& Shkarubo, this volume; Franke \&

597 Hinz, 2009; Drachev, 2011). A complex transtensional setting would not allow a simple

598 interpretation of the stress regime, yet comparison with the present-day geopotential stress

599 field shows clear alignment which could mean that the orientation of faults represent the

600 direction of greatest compressive stress. Since we cannot establish more than the alignment

601 of faults and geopotential stress field, we further discuss whether the faults represent the

602 direction of most compressive stress or whether these have formed independently, during a

603 purely transtensional setting, below.

\section{DISCUSSION}

605 Due to the overall good agreement between the geopotential stress field and WSM, we

606 continue with the assumption that the computed stresses are a realistic representation of the

607 contemporary stress field. We acknowledge that there may be errors in some regions of the

608 calculated geopotential stress, though these are likely spatially limited and we attempt to

609 explain them. With these caveats, the agreement or disagreement between the present-day

610 stress field and palaeo-stress indicators may therefore constrain when the stress field was

611 last adjusted. This is only possible in areas where dykes or extensional basins of known age

612 are present. However, in areas of largely homogenous stress orientations and similar

613 geological settings we extrapolate our conclusions over a broader area. 
614 In cases where the present stress field deviates from the orientation of structural fabrics, we 615 conclude that the stress field must have changed over time. In contrast, in regions where 616 orientations coincide, the stress field is interpreted to have remained unchanged, although 617 we are aware that such an alignment may be coincidental. We emphasise that rifting or 618 even the emplacement of dykes can follow inherited zones of weakness and may not 619 entirely coincide with the actual large-scale stress field. Major tectono-thermal events have 620 affected the High Arctic (e.g. subduction and collision zones) and their imprint may have 621 dissipated with time. The "passive" geopotential stress field studied here does not include 622 such sources, but since the assemblage of the Arctic part of Gondwana at approximately $623250 \mathrm{Ma}$, subduction has not dominated the tectonic evolution in the High Arctic. An 624 exception could be the Eurekan Orogen, where subduction scenarios have been suggested 625 (Brozena et al., 2003; Døssing et al., 2014), but it may also reflect intraplate orogenesis 626 without a subduction component (Tessensohn \& Piepjohn, 2000). Northward Palaeo627 Pacific subduction beneath eastern Siberia and Alaska since c. 130 Ma may have had a 628 major impact on the Early Cretaceous stress field and the subducting Pacific plate 629 influences the far-field stress field in the High Arctic still today.

630 We presented evidence for Early Cretaceous dykes and graben structures on Bennett Island. 631 Reconstruction of a rotational opening of the Amerasia Basin either along a strike-slip fault 632 following the Lomonosov Ridge (e.g. Embry, 1990) or the Alpha Ridge (Dore et al., 2015) 633 would place Bennett Island and the dykes and graben proximal to northernmost Canada, 634 Svalbard and Franz Josefs Land, and the HALIP dyke swarm (Drachev \& Saunders, 2003). 635 Similarly, if the New Siberian Islands were rotated back into a position in proximity to 636 Semeraya Zemlya as a northern continuation of the Uralides (Pease, 2011), these would 637 align with the Taimyr dyke swarm. These two regions were clearly modified by rifting of 638 the Laptev Sea Basin, at later stage, indicated by the stress field.

639 The most convincing regions in which the present-day stress field coincides with palaeo640 stress markers are given in figure 6 and include: First, North Greenland and the adjacent 641 eastern Amerasia Basin, including parts of the Alpha ridge. Here, the lithosphere stress 642 field seems to have remained unaltered since the Late Cretaceous (orange), whereas any 643 effect of the stress field observed in the large radiating dyke swarms of the Early 644 Cretaceous HALIP event (green) seems to have dissipated. The interpretation that the 
orientation and alkaline composition of the Late Cretaceous dyke complexes of North Greenland witnessed prolonged continental-type rifting related to rifting of Greenland away from North America, unrelated to the Early Cretaceous HALIP (Tegner et al., 2011; Thórarinsson et al., 2015), supports this view. Even Early Cretaceous rift axes in the Amerasia Basin roughly coincide with the geopotential stress field, which emphasises the brevity of the stress field change during the Early Cretaceous dyking event. Rifting in the Amerasia Basin may have happened independently from the emplacement of dykes in the Arctic, as suggested by the apparently very different stress regimes during both events.

Second, the stress field in the modern oceanic Eurasia Basin and parts of the North Atlantic, as well as Baffin Bay with its extinct spreading ridge, seems not to have much changed since the Eocene. This does not, however, apply to the northernmost North Atlantic and its connection to the Arctic (Knipovich Ridge and Fram Strait) where highly complex and oblique rifting associated with the transition from the Knipovich Ridge to the Gakkel Ridge and the De Geer transform (Engen et al., 2008) has occurred. Break-up probably followed Caledonian (or older) inherited structures and sutures (Buiter \& Torsvik, 2014; Schiffer et al., 2015b), which implies that the orientation of break-up wasn't necessarily aligned with the large-scale tectonic stress field. This complexity could explain the overall misfit of the rift systems in the adjacent western Barents Sea margin.

Third, late Cretaceous and Cenozoic rifting in the Laptev Sea correspond well with the recent stress field, indicating that no large-scale readjustments have occurred in this area, although seafloor spreading initiated along the Gakkel ridge in the Eocene. Supposedly Cenozoic rifting in the East Siberian Sea is also aligned with the present-day geopotential stress field, yet these rifts are thought to have formed under transtensional deformation. Permo-Triassic dykes on the New Siberian Islands show a very similar orientation, but these might be rotated as mentioned above, while Early Cretaceous dykes on Bennett Island are not aligned. Like the HALIP dykes, this could indicate that the Early Cretaceous structures on Bennett Island were emplaced during a short-lived, transient deviation of the lithospheric stress field. The coincidence of the Permo-Triassic dykes, the Late Cretaceous rift systems and the present-day stress field indicate that the ambient stress field may have existed over a long time, and only was temporarily modified during a short-lived Early Cretaceous dyking event. 
676 Finally, the stress field in the Kara Sea, Taimyr and the West Siberian Basin may have

677 undergone final adjustment in the Triassic shortly after Siberian Trap magmatism. The data

678 do not suggest major changes in the lithospheric stress field after the formation of the

679 Triassic rift basins and dykes, largely due to the close alignment of the calculated stress

680 field in these locations.

681 As a result of the very homogeneous stress field and a similar origin and age, we speculate

682 that the stress field across the eastern Eurasia Basin, the Canadian Arctic Islands and North

683 and Northwest Greenland may have been adjusted during the Late Cretaceous. The stress

684 field in the central and western Amerasia Basin may have been established in the Early

685 Cretaceous. Similarly, the eastern Russian Arctic shelf and the region north of the Bering

686 Strait $\left(\sim 180^{\circ} \mathrm{W}\right)$ may be Cenozoic in age, but given the very similar orientation of

687 structures and stress field in the adjacent western Amerasia Basin, which has primarily

688 Early Cretaceous structures, we speculate the Eastern Russian Arctic shelf could also be of

689 Early Cretaceous age.

690 Two regions of distinct complexity are immediately apparent. The western Barents Sea-

691 Fram Strait-Knipovich Ridge region has a complex stress field and a complex succession of

692 structures of different ages; the WSM neither coincides with the computed stresses nor

693 structures. The area east of Taimyr and west of the New Siberian Islands $\left(\sim 120^{\circ} \mathrm{E}\right)$ shows

694 strong structural complexity, misfit between the WSM and computed stresses, as well

695 between structures and stress field. Both regions are situated at the edge of the thick

696 lithosphere and sharp LAB depth gradients, which might be one of many possible reasons

697 for this misfit. Large gradients in LAB depth produce a large gradient in GPE and,

698 therefore, have a large impact on the direction of the geopotential stress field. As mentioned

699 previously, stress measurements from borehole breakouts have been used in the western

700 Barents Sea and in the Beaufort Sea and the differing depth sensitivities between these two

701 methods may explain parts of the apparent misfit of the computed stress field and the

702 WSM.

703

704 SUMMARY 
We present a new interpretation of the lithospheric stress field of the High Arctic at the present-day and over geologic history, using a calculated geopotential stress field in comparison with palaeo-stress indicators, such as magmatic dykes and extensional basins. A lithospheric density model, compiled from new sedimentary thickness, crustal thickness, dynamic topography and LAB depth models, was used to calculate geopotential energy and the geopotential stress field. We collected published occurrences of mafic dykes and extensional basins in the High Arctic and included new observations from Bennett Island of the De Long Islands, where Early Cretaceous dykes and an associated Graben structure were recognised. We utilised these structures as palaeo-stress indicators and compared them to the previously computed representation of the present-day stress field. We assumed that areas of matching palaeo- and present-day stress directions may provide a minimum age of the last stress field configuration. Conversely, a mismatch may indicate that the stress field was subsequently reconfigured.

We conclude that despite the oldest sedimentary basins in the Barents Sea region and few other exceptions, all major rift basins appear to align with our model of contemporary geopotential stress. Furthermore, Late Cretaceous dykes in northern Greenland and PermoTriassic dykes on Taimyr show this same alignment and may be indicative for the time of the last lithospheric modification in these areas. This is in large contrast to the orientation of Early Cretaceous dykes, none of which align with the computed stress field, indicating a short-lived deviation from the ambient stress field. Early Cretaceous dykes, related to the HALIP and extensional structures related to the opening of the Eurasia Basin do not show similar orientations, implying that these two events (HALIP and Amerasia Basin opening) were distinct in time.

\section{ACKNOWLEDGMENTS}

This paper was produced during a postdoctoral fellowship of C. Schiffer, financed by the Carlsberg Foundation. Thanks go to the Circum Arctic Lithospheric Evolution (CALE) project and all active participants for many constructive discussions at excellent workshops and meetings. This study was largely motivated during CALE activities. Thanks to Nina Lebedeva-Ivanova for providing the Arctic crustal data set. A. Schaeffer is funded by a Natural Sciences and Engineering Research Council (NSERC) of Canada Postdoctoral 
736 Fellowship, V. Pease by the Swedish Research Council and C. Tegner by the Danish

737 National Research Foundation. We appreciate the constructive comments and suggestions

738 from Tony Doré and an anonymous reviewer that helped improving the paper.

\section{REFERENCES CITED}

741

742

743

744

745

746

747

748

749

750

751

752

753

754

755

756

757

758

759

760

761

762

763

764

765

766

767

768

769

770

771

Altenbernd, T., Jokat, W., Heyde, I., and Damm, V., 2015. Geophysical evidence for the extent of crustal types and the type of margin along a profile in the northeastern Baffin Bay, J. Geophys. Res. Solid Earth, 120, 2015JB012307, doi: 10.1002/2015JB012307.

Alvey, A., Gaina, C., Kusznir, N.J., and Torsvik, T.H., 2008. Integrated crustal thickness mapping and plate reconstructions for the high Arctic, Earth Planet. Sci. Lett., 274, 310-321, doi: 10.1016/j.epsl.2008.07.036.

Anfinson, O.A., Leier, A.L., Gaschnig, R., Embry, A.F., and Dewing, K., 2012. U-Pb and Hf isotopic data from Franklinian Basin strata: insights into the nature of Crockerland and the timing of accretion, Canadian Arctic Islands, Can. J. Earth Sci., 49, 1316-1328, doi: 10.1139/e2012-067.

Anudu, G.K., Stephenson, R.A., Macdonald, D.I.M., and Oakey, G.N., 2016. Geological features of the north-eastern Canadian Arctic margin (Canada) revealed from analysis of potential field data, Tectonophysics,, doi: 10.1016/j.tecto.2016.03.025.

Artemieva, I.M., 2009. The continental lithosphere: Reconciling thermal, seismic, and petrologic data, Lithos, 109, 23-46, doi: 10.1016/j.lithos.2008.09.015.

Artemieva, I.M., and Thybo, H., 2013. EUNAseis: A seismic model for Moho and crustal structure in Europe, Greenland, and the North Atlantic region, Tectonophysics, 609, 97-153, doi: 10.1016/j.tecto.2013.08.004.

Beranek, L.P., Mortensen, J.K., Lane, L.S., Allen, T.L., Fraser, T.A., Hadlari, T., and Zantvoort, W.G., 2010. Detrital zircon geochronology of the western Ellesmerian clastic wedge, northwestern Canada: Insights on Arctic tectonics and the evolution of the northern Cordilleran miogeocline, Geol. Soc. Am. Bull., 122, 1899-1911, doi: 10.1130/B30120.1.

Bird, P., and Piper, K., 1980. Plane-stress finite-element models of tectonic flow in southern California, Phys. Earth Planet. Inter., 21, 158-175, doi: 10.1016/0031-9201(80)90067-9.

Bouhifd, M.A., Andrault, D., Fiquet, G., and Richet, P., 1996. Thermal expansion of forsterite up to the melting point, Geophys. Res. Lett., 23, 1143-1146, doi: 10.1029/96GL01118.

Brozena, J.M., Childers, V.A., Lawver, L.A., Gahagan, L.M., Forsberg, R., Faleide, J.I., and Eldholm, O., 2003. New aerogeophysical study of the Eurasia Basin and Lomonosov Ridge: Implications for basin development, Geology, 31, 825-828, doi: 10.1130/G19528.1.

Brumley, K., 2010. Tectonic Geomorphology of the Chukchi Borderland: Constraint for Tectonic Reconstruction Models [M.S. thesis]: University of Alaska, $116 \mathrm{p}$. 
Buchan, K.L., and Ernst, R.E., 2006. The High Arctic Large Igneous Province (HALIP): Evidence for an Associated Giant Radiating Dyke Swarm, High Arct. Large Igneous Prov. HALIP Evid. Assoc. Giant Radiat. Dyke Swarm,.

Buiter, S.J.H., and Torsvik, T.H., 2014. A review of Wilson Cycle plate margins: A role for mantle plumes in continental break-up along sutures?, Gondwana Res., 26, 627-653, doi: 10.1016/j.gr.2014.02.007.

Chalmers, J.A., and Pulvertaft, T.C.R., 2001. Development of the continental margins of the Labrador Sea: a review, Geol. Soc. Lond. Spec. Publ., 187, 77-105, doi: 10.1144/GSL.SP.2001.187.01.05.

Cocks, L.R.M., and Torsvik, T.H., 2007. Siberia, the wandering northern terrane, and its changing geography through the Palaeozoic, Earth-Sci. Rev., 82, 29-74, doi: 10.1016/j.earscirev.2007.02.001.

Conrad, C.P., and Lithgow-Bertelloni, C., 2006. Influence of continental roots and asthenosphere on plate-mantle coupling, Geophys. Res. Lett., 33, L05312, doi: 10.1029/2005GL025621.

Corfu, F., Polteau, S., Planke, S., Faleide, J.I., Svensen, H., Zayoncheck, A., and Stolbov, N., 2013. U$\mathrm{Pb}$ geochronology of Cretaceous magmatism on Svalbard and Franz Josef Land, Barents Sea Large Igneous Province, Geol. Mag., 150, 1127-1135, doi: 10.1017/S0016756813000162.

Curtis, M., Lopez-Mir, B., Scott, R., and Howard, J.P., this volume. Triassic sinistral transpression along the Pai-Khoi fold and thrust belt, Russia: Implications for the structural interpretation of southernmost Novaya Zemlya, Geol. Soc. Spec. Publ.,.

Danukalova, M.K., Kuzmichev, A.B., and Aristov, V.A., 2014. Upper Devonian depositional system of Bel'kov Island (New Siberian Islands): An intracontinental rift or a continental margin?, Geotectonics, 48, 390-412, doi: 10.1134/S0016852114050021.

Dibner, V.D. (Ed.), 1998. Geology of Franz Josef Land:

Doré, A.G., Lundin, E.R., Gibbons, A., Sømme, T.O., and Tørudbakken, B.O., 2015. Transform margins of the Arctic: a synthesis and re-evaluation, Geol. Soc. Lond. Spec. Publ., 431, SP431.8, doi: 10.1144/SP431.8.

Døssing, A., Hansen, T.M., Olesen, A.V., Hopper, J.R., and Funck, T., 2014. Gravity inversion predicts the nature of the Amundsen Basin and its continental borderlands near Greenland, Earth Planet. Sci. Lett., 408, 132-145, doi: 10.1016/j.epsl.2014.10.011.

Døssing, A., Hopper, J.R., Olesen, A.V., Rasmussen, T.M., and Halpenny, J., 2013a. New aerogravity results from the Arctic: Linking the latest Cretaceous-early Cenozoic plate kinematics of the North Atlantic and Arctic Ocean, Geochem. Geophys. Geosystems, 14, 4044-4065, doi: 10.1002/ggge.20253.

Døssing, A., Jackson, H.R., Matzka, J., Einarsson, I., Rasmussen, T.M., Olesen, A.V., and Brozena, J.M., 2013b. On the origin of the Amerasia Basin and the High Arctic Large Igneous Province-Results of new aeromagnetic data, Earth Planet. Sci. Lett., 363, 219-230, doi: 10.1016/j.epsl.2012.12.013. 
Drachev, S.S., 2011. Chapter 25 Tectonic setting, structure and petroleum geology of the Siberian Arctic offshore sedimentary basins, Geol. Soc. Lond. Mem., 35, 369-394, doi: 10.1144/M35.25.

Drachev, S.S., 2016. Fold belts and sedimentary basins of the Eurasian Arctic, arktos, 2, 1-30, doi: 10.1007/s41063-015-0014-8.

Drachev, S.S., Kaul, N., and Beliaev, V.N., 2003. Eurasia spreading basin to Laptev Shelf transition: structural pattern and heat flow, Geophys. J. Int., 152, 688-698, doi: 10.1046/j.1365246X.2003.01882.x.

Drachev, S.S., Malyshev, N.A., and Nikishin, A.M., 2010. Tectonic history and petroleum geology of the Russian Arctic Shelves: an overview, Geol. Soc. Lond. Pet. Geol. Conf. Ser., 7, 591-619, doi: 10.1144/0070591.

Drachev, S., and Saunders, A., 2003. The Early Cretaceous Arctic LIP: its geodynamic setting and implications for Canada Basin opening, in Proceedings of the Fourth Int. Conf. on Arctic Margins, OCS Study, MMS 2006-003, Anchorage, p. 216-223.

Drachev, S.S., and Shkarubo, S., this volume. Tectonics of the Laptev Shelf, Siberian Arctic, Geol. Soc. Spec. Publ.,.

Dutro, J.T., 1981. Geology of Alaska Bordering the Arctic Ocean, in Nairn, A.E.M., Churkin, M., and Stehli, F.G. eds., The Arctic Ocean, Springer US, p. 21-36.

Eaton, D.W., Darbyshire, F., Evans, R.L., Grütter, H., Jones, A.G., and Yuan, X., 2009. The elusive lithosphere-asthenosphere boundary (LAB) beneath cratons, Lithos, 109, 1-22, doi: 10.1016/j.lithos.2008.05.009.

Ebbing, J., England, R.W., Korja, T., Lauritsen, T., Olesen, O., Stratford, W., and Weidle, C., 2012. Structure of the Scandes lithosphere from surface to depth, Tectonophysics, 536-537, 124, doi: 10.1016/j.tecto.2012.02.016.

Embry, A.F., 1990. Geological and geophysical evidence in support of the hypothesis of anticlockwise rotation of northern Alaska, Mar. Geol., 93, 317-329, doi: 10.1016/00253227(90)90090-7.

Embry, A.F., 1991. Mesozoic history of the Arctic Islands, in Trettin, H.P. ed., Geology of the Innuitian Orogen and Arctic Platform of Canada and Greenland, Geology of Canada 3, Geological Survey of Canada, p. 371-433.

Embry, A., and Beauchamp, B., 2008. Chapter 13 Sverdrup Basin, in Andrew D. Miall ed., Sedimentary Basins of the World, The Sedimentary Basins of the United States and Canada, Elsevier, p. 451-471.

Embry, A.F., and Dixon, J., 1990. The breakup unconformity of the Amerasia Basin, Arctic Ocean: Evidence from Arctic Canada, Geol. Soc. Am. Bull., 102, 1526-1534, doi: 10.1130/00167606(1990)102<1526:TBUOTA>2.3.CO;2.

Engen, $\varnothing .$, Eldholm, O., and Bungum, H., 2003. The Arctic plate boundary: THE ARCTIC PLATE BOUNDARY, J. Geophys. Res. Solid Earth, 108, doi: 10.1029/2002JB001809. 
849

850

851

852

853

854

855

856

857

858

859

860

861

862

863

864

865

866

867

868

869

870

871

872

873

874

875

876

877

878

879

880

881

882

883

884

885

886

Engen, $\varnothing$., Faleide, J.I., and Dyreng, T.K., 2008. Opening of the Fram Strait gateway: A review of plate tectonic constraints, Tectonophysics, 450, 51-69, doi: 10.1016/j.tecto.2008.01.002.

England, P., and Houseman, G., 1986. Finite strain calculations of continental deformation: 2. Comparison with the India-Asia Collision Zone, J. Geophys. Res. Solid Earth, 91, 3664-3676, doi: 10.1029/JB091iB03p03664.

England, P., and McKenzie, D., 1982. A thin viscous sheet model for continental deformation, Geophys. J. R. Astron. Soc., 70, 295-321, doi: 10.1111/j.1365-246X.1982.tb04969.x.

Estrada, S., and Henjes-Kunst, F., 2013. 40Ar-39Ar and U-Pb dating of Cretaceous continental riftrelated magmatism on the northeast Canadian Arctic margin [40Ar-39Ar- und U-PbDatierung des kretazischen kontinentalen Rift-Magmatismus am Nordostrand der kanadischen Arktis.], Z. Dtsch. Ges. Für Geowiss., 164, 107-130, doi: 10.1127/18601804/2013/0005.

Estrada, S., Henjes-Kunst, F., Melcher, F., and Tessensohn, F., 2010. Paleocene alkaline volcanism in the Nares Strait region: evidence from volcanic pebbles, Int. J. Earth Sci., 99, 863-890, doi: 10.1007/s00531-009-0432-6.

Evenchick, C.A., Davis, W.J., Bédard, J.H., Hayward, N., and Friedman, R.M., 2015. Evidence for protracted High Arctic large igneous province magmatism in the central Sverdrup Basin from stratigraphy, geochronology, and paleodepths of saucer-shaped sills, Geol. Soc. Am. Bull.,, B31190.1, doi: 10.1130/B31190.1.

Faleide, I.J., Pease, V., Curtis, M., Klitzke, P., Minakov, A., Kostyuchenko, S., Zayonchek, A., and Scheck-Wenderoth, M., this volume. Lithospheric transects across the Barents and Kara shelves, and tectonic implications, Geol. Soc. Spec. Publ.,.

Faleide, J.I., Tsikalas, F., Breivik, A.J., Mjelde, R., Ritzmann, O., Engen, Ø., Wilson, J., and Eldholm, O., 2008. Structure and evolution of the continental margin off Norway and the Barents Sea, Episodes, 31, 82-91.

Fischer, K.M., Ford, H.A., Abt, D.L., and Rychert, C.A., 2010. The Lithosphere-Asthenosphere Boundary, Annu. Rev. Earth Planet. Sci., 38, 551-575, doi: 10.1146/annurev-earth-040809152438.

Flesch, L.M., Haines, A.J., and Holt, W.E., 2001. Dynamics of the India-Eurasia collision zone, J. Geophys. Res. Solid Earth, 106, 16435-16460, doi: 10.1029/2001JB000208.

Franke, D., and Hinz, K., 2009. Geology of the Shelves surrounding the New Siberian Islands, Russian Arctic, Stephan Mueller Spec Publ Ser, 4, 35- 44.

Franke, D., Hinz, K., and Oncken, O., 2001. The Laptev Sea Rift, Mar. Pet. Geol., 18, 1083-1127, doi: 10.1016/S0264-8172(01)00041-1.

Franke, D., Hinz, K., and Reichert, C., 2004. Geology of the East Siberian Sea, Russian Arctic, from seismic images: Structures, evolution, and implications for the evolution of the Arctic Ocean Basin: GEOLOGY OF THE EAST SIBERIAN SHELF, J. Geophys. Res. Solid Earth, 109, doi: $10.1029 / 2003 J B 002687$. 
Funck, T., Gohl, K., Damm, V., and Heyde, I., 2012. Tectonic evolution of southern Baffin Bay and Davis Strait: Results from a seismic refraction transect between Canada and Greenland, J. Geophys. Res. Solid Earth, 117, doi: 10.1029/2011JB009110.

Funck, T., Jackson, H.R., and Shimeld, J., 2011. The crustal structure of the Alpha Ridge at the transition to the Canadian Polar Margin: Results from a seismic refraction experiment, $J$. Geophys. Res. Solid Earth, 116, B12101, doi: 10.1029/2011JB008411.

Gaina, C., Medvedev, S., Torsvik, T.H., Koulakov, I., and Werner, S.C., 2013. 4D Arctic: A Glimpse into the Structure and Evolution of the Arctic in the Light of New Geophysical Maps, Plate Tectonics and Tomographic Models, Surv. Geophys., 35, 1095-1122, doi: 10.1007/s10712013-9254-y.

Gaina, C., Nikishin, A.M., and Petrov, E.I., 2015. Ultraslow spreading, ridge relocation and compressional events in the East Arctic region: A link to the Eurekan orogeny?, arktos, 1, 1-11, doi: 10.1007/s41063-015-0006-8.

Gaina, C., Werner, S.C., Saltus, R., and Maus, S., 2011. Chapter 3 Circum-Arctic mapping project: new magnetic and gravity anomaly maps of the Arctic, Geol. Soc. Lond. Mem., 35, 39-48, doi: 10.1144/M35.3.

Gasser, D., 2013. The Caledonides of Greenland, Svalbard and other Arctic areas: status of research and open questions, Geol. Soc. Lond. Spec. Publ., 390, 93-129, doi: 10.1144/SP390.17.

Gee, D.G., 2015. Caledonides of Scandinavia, Greenland, and Svalbard, in Elias, S.A. ed., Reference Module in Earth Systems and Environmental Sciences, Elsevier.

Gee, D.G., Fossen, H., Henriksen, N., and Higgins, A.K., 2008. From the early Paleozoic platforms of Baltica and Laurentia to the Caledonide orogen of Scandinavia and Greenland, in Episodes, Episodes.

Gee, D.G., and Pease, V., 2004. The Neoproterozoic Timanide Orogen of eastern Baltica: introduction, Geol. Soc. Lond. Mem., 30, 1-3, doi: 10.1144/GSL.MEM.2004.030.01.01.

Gernigon, L., Blischke, A., Nasuti, A., and Sand, M., 2015. Conjugate volcanic rifted margins, seafloor spreading and microcontinent: Insights from new high-resolution aeromagnetic surveys in the Norway Basin, Tectonics,, 2014TC003717, doi: 10.1002/2014TC003717.

Ghosh, A., Holt, W.E., Wen, L., Haines, A.J., and Flesch, L.M., 2008. Joint modeling of lithosphere and mantle dynamics elucidating lithosphere-mantle coupling, Geophys. Res. Lett., 35, L16309, doi: 10.1029/2008GL034365.

Glebovsky, V.Y., Kaminsky, V.D., Minakov, A.N., Merkur'ev, S.A., Childers, V.A., and Brozena, J.M., 2006. Formation of the Eurasia Basin in the Arctic Ocean as inferred from geohistorical analysis of the anomalous magnetic field, Geotectonics, 40, 263-281, doi: $10.1134 /$ S0016852106040029.

Grad, M., Tiira, T., and ESC Working Group, 2009. The Moho depth map of the European Plate, Geophys. J. Int., 176, 279-292, doi: 10.1111/j.1365-246X.2008.03919.x. 
Grantz, A., Clark, D.L., Phillips, R.L., Srivastava, S.P., Blome, C.D., Gray, L.B., Haga, H., Mamet, B.L., McIntyre, D.J., McNeil, D.H., Mickey, M.B., Mullen, M.W., Murchey, B.I., Ross, C.A., et al., 1998. Phanerozoic stratigraphy of Northwind Ridge, magnetic anomalies in the Canada basin, and the geometry and timing of rifting in the Amerasia basin, Arctic Ocean, Geol. Soc. Am. Bull., 110, 801-820, doi: 10.1130/0016-7606(1998)110<0801:PSONRM>2.3.CO;2.

Grantz, A., Hart, P.E., and Childers, V.A., 2011. Chapter 50 Geology and tectonic development of the Amerasia and Canada Basins, Arctic Ocean, Geol. Soc. Lond. Mem., 35, 771-799, doi: 10.1144/M35.50.

Grantz, A., Pease, V.L., Willard, D.A., Phillips, R.L., and Clark, D.L., 2001. Bedrock cores from $89^{\circ}$ North: Implications for the geologic framework and Neogene paleoceanography of Lomonosov Ridge and a tie to the Barents shelf, Geol. Soc. Am. Bull., 113, 1272-1281, doi: 10.1130/0016-7606(2001)113<1272:BCFNIF>2.0.CO;2.

Gudlaugsson, S.T., Faleide, J.I., Johansen, S.E., and Breivik, A.J., 1998. Late Palaeozoic structural development of the South-western Barents Sea, Mar. Pet. Geol., 15, 73-102, doi: 10.1016/S0264-8172(97)00048-2.

Håkansson, E., and Stemmerik, L., 1989. Wandel Sea basin-A new synthesis of the late Paleozoic to Tertiary accumulation in North Greenland, Geology, 17, 683-686, doi: 10.1130/00917613(1989)017<0683:WSBANS>2.3.CO;2.

Heidbach, O., Tingay, M., Barth, A., Reinecker, J., Kurfeß, D., and Müller, B., 2010. Global crustal stress pattern based on the World Stress Map database release 2008, Tectonophysics, 482, 3-15, doi: 10.1016/j.tecto.2009.07.023.

Henriksen, E., Ryseth, A.E., Larssen, G.B., Heide, T., Rønning, K., Sollid, K., and Stoupakova, A.V., 2011. Chapter 10 Tectonostratigraphy of the greater Barents Sea: implications for petroleum systems, Geol. Soc. Lond. Mem., 35, 163-195, doi: 10.1144/M35.10.

Hosseinpour, M., Müller, R.D., Williams, S.E., and Whittaker, J.M., 2013. Full-fit reconstruction of the Labrador Sea and Baffin Bay, Solid Earth, 4, 461-479, doi: 10.5194/se-4-461-2013.

Inger, S., Scott, R.A., and Golionko, B.G., 1999. Tectonic evolution of the Taimyr Peninsula, northern Russia: implications for Arctic continental assembly, J. Geol. Soc., 156, 10691072, doi: 10.1144/gsjgs.156.6.1069.

Ivanov, A.V., He, H., Yan, L., Ryabov, V.V., Shevko, A.Y., Palesskii, S.V., and Nikolaeva, I.V., 2013. Siberian Traps large igneous province: Evidence for two flood basalt pulses around the Permo-Triassic boundary and in the Middle Triassic, and contemporaneous granitic magmatism, Earth-Sci. Rev., 122, 58-76, doi: 10.1016/j.earscirev.2013.04.001.

Ivanova, N.M., Sakulina, T.S., Belyaev, I.V., Matveev, Y.I., and Roslov, Y.V., 2011. Chapter 12 Depth model of the Barents and Kara seas according to geophysical surveys results, Geol. Soc. Lond. Mem., 35, 209-221, doi: 10.1144/M35.12.

Jackson, H.R., Dahl-Jensen, T., and LORITA working group, 2010. Sedimentary and crustal structure from the Ellesmere Island and Greenland continental shelves onto the Lomonosov Ridge, Arctic Ocean, Geophys. J. Int., 182, 11-35, doi: 10.1111/j.1365-246X.2010.04604.x. 
Jokat, W., 2003. Seismic investigations along the western sector of Alpha Ridge, Central Arctic Ocean, Geophys. J. Int., 152, 185-201, doi: 10.1046/j.1365-246X.2003.01839.x.

Jokat, W., Uenzelmann-Neben, G., Kristoffersen, Y., and Rasmussen, T.M., 1992. Lomonosov Ridge-A double-sided continental margin, Geology, 20, 887-890, doi: 10.1130/00917613(1992)020<0887:LRADSC>2.3.CO;2.

Kennett, B.L.N., Engdahl, E.R., and Buland, R., 1995. Constraints on seismic velocities in the Earth from traveltimes, Geophys. J. Int., 122, 108-124, doi: 10.1111/j.1365246X.1995.tb03540.x.

Klimenko, S.S., Anischenko, L.A., and Antoshkina, A.I., 2011. Chapter 13 The Timan-Pechora sedimentary basin: Palaeozoic reef formations and petroleum systems, Geol. Soc. Lond. Mem., 35, 223-236, doi: 10.1144/M35.13.

Klitzke, P., Faleide, J.I., Scheck-Wenderoth, M., and Sippel, J., 2015. A lithosphere-scale structural model of the Barents Sea and Kara Sea region, Solid Earth, 6, 153-172, doi: 10.5194/se-6153-2015.

Kravchinsky, V.A., Cogné, J.-P., Harbert, W.P., and Kuzmin, M.I., 2002. Evolution of the MongolOkhotsk Ocean as constrained by new palaeomagnetic data from the Mongol-Okhotsk suture zone, Siberia, Geophys. J. Int., 148, 34-57, doi: 10.1046/j.1365-246x.2002.01557.x.

Kuzmichev, A.B., and Pease, V.L., 2007. Siberian trap magmatism on the New Siberian Islands: constraints for Arctic Mesozoic plate tectonic reconstructions, J. Geol. Soc., 164, 959-968, doi: 10.1144/0016-76492006-090.

Lane, L.S., 1997. Canada Basin, Arctic Ocean: Evidence against a rotational origin, Tectonics, 16, 363-387, doi: 10.1029/97TC00432.

Laske, G., Masters, G., Ma, Z., and Pasyanos, M., 2013. Update on CRUST1.0 - A 1-degree Global Model of Earth's Crust, in Geophysical Research Abstracts,.

Lawver, L.A., Gahagan, L.M., and Norton, I., 2011. Chapter 5 Palaeogeographic and tectonic evolution of the Arctic region during the Palaeozoic, Geol. Soc. Lond. Mem., 35, 61-77, doi: 10.1144/M35.5.

Lebedev, S., and Van Der Hilst, R.D., 2008. Global upper-mantle tomography with the automated multimode inversion of surface and S-wave forms, Geophys. J. Int., 173, 505-518, doi: 10.1111/j.1365-246X.2008.03721.x.

Lebedeva-Ivanova, N.N., Gaina, C., Minakov, A., and Kashubin, S., 2015. A new model of the Arctic crustal thickness from 3D gravity inversion, in AGU Fall Meeting Abstracts,.

Lebedeva-Ivanova, N., Gaina, C., Minakov, A., and Kashubin, S., 2016. ArcCRUST: Arctic Moho and crustal thickness from 3D gravity inversion, Earth Planet. Sci. Lett., under review.

Lebedeva-Ivanova, N.N., Gee, D.G., and Sergeyev, M.B., 2011. Chapter 26 Crustal structure of the East Siberian continental margin, Podvodnikov and Makarov basins, based on refraction seismic data (TransArctic 1989-1991), Geol. Soc. Lond. Mem., 35, 395-411, doi: 10.1144/M35.26. 
1002

1003

1004

1005

1006

1007

1008

1009

1010

1011

1012

1013

1014

1015

1016

1017

1018

1019

1020

1021

1022

1023

1024

1025

1026

1027

1028

1029

1030

1031

1032

1033

1034

1035

1036

1037

1038

1039

Lebedeva-Ivanova, N.N., Zamansky, Y.Y., Langinen, A.E., and Sorokin, M.Y., 2006. Seismic profiling across the Mendeleev Ridge at $82^{\circ} \mathrm{N}$ : evidence of continental crust, Geophys. J. Int., 165, 527-544, doi: 10.1111/j.1365-246X.2006.02859.x.

Lemieux, Y., Hadlari, T., and Simonetti, A., 2011. Detrital zircon geochronology and provenance of Devono-Mississippian strata in the northern Canadian Cordilleran miogeocline, Can. J. Earth Sci., 48, 515-541, doi: 10.1139/E10-056.

Leslie, A.G., Smith, M., and Scoper, N.J., 2008. Laurentian margin evolution and the Caledonian orogeny - A template for Scotland and East Greenland, in The Greenland Caledonides, GSA Memoirs 202, The Geological Society of America.

Li, L., Stephenson, R., and Clift, P.D., 2016. The Canada Basin compared to the Southwest South China Sea: Two marginal ocean basins with hyper-extended continent-ocean transitions, Tectonophysics,, doi: 10.1016/j.tecto.2016.02.042.

Lorenz, H., Gee, D.G., Larionov, A.N., and Majka, J., 2012. The Grenville-Sveconorwegian orogen in the high Arctic, Geol. Mag., 149, 875-891, doi: 10.1017/S0016756811001130.

Maher, J., Harmon D., 2001. Manifestations of the Cretaceous High Arctic Large Igneous Province in Svalbard, J. Geol., 109, 91-104, doi: 10.1086/317960.

Marello, L., Ebbing, J., and Gernigon, L., 2013. Basement inhomogeneities and crustal setting in the Barents Sea from a combined 3D gravity and magnetic model, Geophys. J. Int., 193, 557584, doi: $10.1093 /$ gji/ggt018.

McKenzie, D., and Bickle, M.J., 1988. The volume and composition of melt generated by extension of the lithosphere, J. Petrol., 29, 625-679, doi: 10.1093/petrology/29.3.625.

McKenzie, D., Jackson, J., and Priestley, K., 2005. Thermal structure of oceanic and continental lithosphere, Earth Planet. Sci. Lett., 233, 337-349, doi: 10.1016/j.epsl.2005.02.005.

Minakov, A., Faleide, J.I., Glebovsky, V.Y., and Mjelde, R., 2012. Structure and evolution of the northern Barents-Kara Sea continental margin from integrated analysis of potential fields, bathymetry and sparse seismic data, Geophys. J. Int., 188, 79-102, doi: 10.1111/j.1365246X.2011.05258.x.

Morozov, A.F., Petrov, O.V., Shokalsky, S.P., Kashubin, S.N., Kremenetsky, A.A., Shkatov, M.Y., Kaminsky, V.D., Gusev, E.A., Grikurov, G.E., Rekant, P.V., and others, 2012. New geological data are confirming continental origin of the central Arctic rises, expedition, 2012.

Mosar, J., Lewis, G., and Torsvik, T., 2002. North Atlantic sea-floor spreading rates: implications for the Tertiary development of inversion structures of the Norwegian-Greenland Sea, J. Geol. Soc., 159, 503-515, doi: 10.1144/0016-764901-135.

Mosher, D.C., Shimeld, J., Hutchinson, D., Chian, D., Lebedova-Ivanova, N., and Jackson, R., 2012. Canada Basin Revealed, in Offshore Technology Conference.

Müller, R.D., Sdrolias, M., Gaina, C., and Roest, W.R., 2008. Age, spreading rates, and spreading asymmetry of the world's ocean crust, Geochem. Geophys. Geosystems, 9, Q04006, doi: 10.1029/2007GC001743. 
1040

1041

1042

1043

1044

1045

1046

1047

1048

1049

1050

1051

1052

1053

1054

1055

1056

1057

1058

1059

1060

1061

1062

1063

1064

1065

1066

1067

1068

1069

1070

1071

1072

1073

1074

1075

Nielsen, S.B., Stephenson, R., and Schiffer, C., 2014. Deep controls on intraplate basin inversion, in Talwani, P. ed., Intraplate Earthquakes, Cambridge University Press.

Nielsen, S.B., Stephenson, R., and Thomsen, E., 2007. Dynamics of Mid-Palaeocene North Atlantic rifting linked with European intra-plate deformations, Nature, 450, 1071-1074, doi: 10.1038/nature06379.

Nikishin, E.I.P., N.A. Malyshev A.M., 2014. Geological Structure and History of the Arctic Ocean:

Nikishin, A.M., Sobornov, K.O., Prokopiev, A.V., and Frolov, S.V., 2010. Tectonic evolution of the Siberian Platform during the Vendian and Phanerozoic, Mosc. Univ. Geol. Bull., 65, 1-16, doi: $10.3103 /$ S0145875210010011.

Nikishin, A.M., Ziegler, P.A., Stephenson, R.A., Cloetingh, S.A.P.L., Furne, A.V., Fokin, P.A., Ershov, A.V., Bolotov, S.N., Korotaev, M.V., Alekseev, A.S., Gorbachev, V.I., Shipilov, E.V., Lankreijer, A., Bembinova, E.Y., et al., 1996. Late Precambrian to Triassic history of the East European Craton: dynamics of sedimentary basin evolution, Tectonophysics, 268, 23-63, doi: 10.1016/S0040-1951(96)00228-4.

Oakey, G.N., and Chalmers, J.A., 2012. A new model for the Paleogene motion of Greenland relative to North America: Plate reconstructions of the Davis Strait and Nares Strait regions between Canada and Greenland, J. Geophys. Res., 117, doi: 10.1029/2011JB008942.

Oakey, G.N., and Stephenson, R., 2008. Crustal structure of the Innuitian region of Arctic Canada and Greenland from gravity modelling: implications for the Palaeogene Eurekan orogen, Geophys. J. Int., 173, 1039-1063, doi: 10.1111/j.1365-246X.2008.03784.x.

Okulitch, A.V., and Trettin, H.P., 1991. Late Cretaceous-Early Tertiary deformation, Arctic Islands, in Trettin, H.P. ed., Geology of the Innuitian Orogen and Arctic Platform of Canada and Greenland, Geology of Canada 3, Geological Survey of Canada, p. 467-485.

Olesen, O., Brönner, M., Ebbing, J., Gellein, J., Gernigon, L., Koziel, J., Lauritsen, T., Myklebust, R., Pascal, C., Sand, M., Solheim, D., and Usov, S., 2010. New aeromagnetic and gravity compilations from Norway and adjacent areas: methods and applications, Geol. Soc. Lond. Pet. Geol. Conf. Ser., 7, 559-586, doi: 10.1144/0070559.

Otto, S.C., and Bailey, R.J., 1995. Tectonic evolution of the northern Ural Orogen, J. Geol. Soc., 152, 903-906, doi: 10.1144/GSL.JGS.1995.152.01.03.

Pease, V., 2011. Chapter 20 Eurasian orogens and Arctic tectonics: an overview, Geol. Soc. Lond. Mem., 35, 311-324, doi: 10.1144/M35.20.

Pease, V., Drachev, S., Stephenson, R., and Zhang, X., 2014. Arctic lithosphere - A review, Tectonophysics, 628, 1-25, doi: 10.1016/j.tecto.2014.05.033.

Pease, V., and Nobre Silva, I., 2015. Age and geochemistry of Cretaceous basalts from Axel Heiberg, Canada, in Smelror, M. ed., 7th International Conference on Arctic Margins ICAM 2015 (Abstracts),. 
1076

1077

1078

1079

1080

1081

1082

1083

1084

1085

1086

1087

1088

1089

1090

1091

1092

1093

1094

1095

1096

1097

1098

1099

1100

1101

1102

1103

1104

1105

1106

1107

1108

1109

1110

1111

1112

1113

Pease, V., and Scott, R.A., 2009. Crustal affinities in the Arctic Uralides, northern Russia: significance of detrital zircon ages from Neoproterozoic and Palaeozoic sediments in Novaya Zemlya and Taimyr, J. Geol. Soc., 166, 517-527, doi: 10.1144/0016-76492008-093.

Pease, V., and Vernikovsky, V., 2000. The tectono-magmatic evolution of the Taimyr peninsula: Further constraints from new ion-microprobe data, Polarforschung, 68, 171-178.

Petrov, O., Morozov, A., Shokalsky, S., Kashubin, S., Artemieva, I.M., Sobolev, N., Petrov, E., Ernst, R.E., Sergeev, S., and Smelror, M., 2016. Crustal structure and tectonic model of the Arctic region, Earth-Sci. Rev., 154, 29-71, doi: 10.1016/j.earscirev.2015.11.013.

Piepjohn, K., Gosen, W. von, and Tessensohn, F., 2016. The Eurekan deformation in the Arctic: an outline, J. Geol. Soc.,, jgs2016-081, doi: 10.1144/jgs2016-081.

Piepjohn, K., and von Gosen, W., This volume. The Ellesmerian Fold-and-Thrust Belt - a geological transect across Ellesmere Island,.

Polteau, S., Hendriks, B.W.H., Planke, S., Ganerød, M., Corfu, F., Faleide, J.I., Midtkandal, I., Svensen, H.S., and Myklebust, R., 2016. The Early Cretaceous Barents Sea Sill Complex: Distribution, 40Ar/39Ar geochronology, and implications for carbon gas formation, Palaeogeogr. Palaeoclimatol. Palaeoecol., 441, 83-95, doi: 10.1016/j.palaeo.2015.07.007.

Poselov, V.A., Verba, V.V., and Zholondz, S.M., 2007. Typification of the Earth's crust of Central Arctic Uplifts in the Arctic Ocean, Geotectonics, 41, 296-305, doi: 10.1134/S0016852107040036.

Reichow, M.K., Pringle, M.S., Al'Mukhamedov, A.I., Allen, M.B., Andreichev, V.L., Buslov, M.M., Davies, C.E., Fedoseev, G.S., Fitton, J.G., Inger, S., Medvedev, A.Y., Mitchell, C., Puchkov, V.N., Safonova, I.Y., et al., 2009. The timing and extent of the eruption of the Siberian Traps large igneous province: Implications for the end-Permian environmental crisis, Earth Planet. Sci. Lett., 277, 9-20, doi: 10.1016/j.epsl.2008.09.030.

Reichow, M.K., Saunders, A.D., Scott, R.A., Millar, I.L., Barfod, D., Pringle, M.S., Rogers, N.W., and Hammond, S., 2016. Petrogenesis and timing of mafic magmatism, South Taimyr, Arctic Siberia: A northerly continuation of the Siberian Traps?, Lithos, 248-251, 382-401, doi: 10.1016/j.lithos.2016.01.018.

Reichow, M.K., Saunders, A.D., White, R.V., Pringle, M.S., Al'Mukhamedov, A.I., Medvedev, A.I., and Kirda, N.P., 2002. 40Ar/39Ar Dates from the West Siberian Basin: Siberian Flood Basalt Province Doubled, Science, 296, 1846-1849, doi: 10.1126/science.1071671.

Ritzmann, O., Maercklin, N., Faleide, I.J., Bungum, H., Mooney, W.D., and Detweiler, S.T., 2007. A three-dimensional geophysical model of the crust in the Barents Sea region: model construction and basement characterization, Geophys. J. Int., 170, 417-435, doi: 10.1111/j.1365-246X.2007.03337.x.

Roberts, D., 2003. The Scandinavian Caledonides: event chronology, palaeogeographic settings and likely modern analogues, Tectonophysics, 365, 283-299, doi: 10.1016/S00401951(03)00026-X. 
1114

1115

1116

1117

1118

1119

1120

1121

1122

1123

1124

1125

1126

1127

1128

1129

1130

1131

1132

1133

1134

1135

1136

1137

1138

1139

1140

1141

1142

1143

1144

1145

1146

1147

1148

1149

1150

1151

Roberts, D., and Olovyanishnikov, V., 2004. Structural and tectonic development of the Timanide orogen, Geol. Soc. Lond. Mem., 30, 47-57, doi: 10.1144/GSL.MEM.2004.030.01.05.

Saltus, R.W., Miller, E.L., Gaina, C., and Brown, P.J., 2011. Chapter 4 Regional magnetic domains of the Circum-Arctic: a framework for geodynamic interpretation, Geol. Soc. Lond. Mem., 35, 49-60, doi: 10.1144/M35.4.

Schaeffer, A.J., and Lebedev, S., 2015a. Global Heterogeneity of the Lithosphere and Underlying Mantle: A Seismological Appraisal Based on Multimode Surface-Wave Dispersion Analysis, Shear-Velocity Tomography, and Tectonic Regionalization, in Khan, A. and Deschamps, F. eds., The Earth's Heterogeneous Mantle, Springer Geophysics, Springer International Publishing, p. 3-46.

Schaeffer, A.J., and Lebedev, S., 2013. Global shear speed structure of the upper mantle and transition zone, Geophys. J. Int., 194, 417-449, doi: 10.1093/gji/ggt095.

Schaeffer, A.J., and Lebedev, S., 2015b. Seismic Tomography of the Arctic Lithosphere and Asthenosphere, in Geophysical Research Abstracts.

Schaeffer, A.J., Lebedev, S., and Gaina, C., submitted. Structure of the Circum-Arctic lithosphere and asthenosphere imaged using multimode waveform tomography, Tectonophysics,.

Schiffer, C., Jacobsen, B.H., Balling, N., Ebbing, J., and Nielsen, S.B., 2015a. The East Greenland Caledonides-teleseismic signature, gravity and isostasy, Geophys. J. Int., 203, 1400-1418, doi: $10.1093 / g j i / g g v 373$.

Schiffer, C., and Nielsen, S.B., 2016. Implications for anomalous mantle pressure and dynamic topography from lithospheric stress patterns in the North Atlantic Realm, J. Geodyn., 98, 53-69, doi: 10.1016/j.jog.2016.03.014.

Schiffer, C., and Stephenson, R.A., this volume. Regional crustal architecture of Ellesmere Island, Arctic Canada, Geol. Soc. Lond. Spec. Publ.,.

Schiffer, C., Stephenson, R., Oakey, G.N., and Jacobsen, B.H., 2016. The crustal structure of Ellesmere Island, Arctic Canada-teleseismic mapping across a remote intraplate orogenic belt, Geophys. J. Int., 204, 1579-1600, doi: 10.1093/gji/ggv539.

Schiffer, C., Stephenson, R.A., Petersen, K.D., Nielsen, S.B., Jacobsen, B.H., Balling, N., and Macdonald, D.I.M., 2015b. A sub-crustal piercing point for North Atlantic reconstructions and tectonic implications, Geology, 43, 1087-1090, doi: 10.1130/G37245.1.

Senger, K., Tveranger, J., Ogata, K., Braathen, A., and Planke, S., 2014. Late Mesozoic magmatism in Svalbard: A review, Earth-Sci. Rev., 139, 123-144, doi: 10.1016/j.earscirev.2014.09.002.

Shephard, G.E., Müller, R.D., and Seton, M., 2013. The tectonic evolution of the Arctic since Pangea breakup: Integrating constraints from surface geology and geophysics with mantle structure, Earth-Sci. Rev., 124, 148-183, doi: 10.1016/j.earscirev.2013.05.012.

Sippel, J., Scheck-Wenderoth, M., Lewerenz, B., and Kroeger, K.F., 2013. A crust-scale 3D structural model of the Beaufort-Mackenzie Basin (Arctic Canada), Tectonophysics, 591, 30-51, doi: 10.1016/j.tecto.2012.10.030. 
1152

1153

1154

1155

1156

1157

1158

1159

1160

1161

1162

1163

1164

1165

1166

1167

1168

1169

1170

1171

1172

1173

1174

1175

1176

1177

1178

1179

1180

1181

1182

1183

1184

1185

1186

1187

1188

1189

Srivastava, S.P., 1985. Evolution of the Eurasian Basin and its implications to the motion of Greenland along Nares Strait, Tectonophysics, 114, 29-53, doi: 10.1016/00401951(85)90006-X.

Stein, C.A., and Stein, S., 1992. A model for the global variation in oceanic depth and heat flow with lithospheric age, Nature, 359, 123-129, doi: 10.1038/359123a0.

Stemmerik, L., Dalhoff, F., Larsen, B.D., Lyck, J., Mathiesen, A., and Nilsson, I., 1998. Wandel Sea Basin, eastern North Greenland, Geol. Greenl. Surv. Bull., 180, 55-62.

Stephenson, R.A., Boerstoel, J., Embry, A.F., and Ricketts, B.D., 1994a. Subsidence analysis and tectonic modelling of the Sverdrup Basin, in 1992 Proceedings, International Conference on Arctic Margins, Anchorage, US Department of the Interior, Minerals Management Service,.

Stephenson, R.A., Coflin, K.C., Lane, L.S., and Dietrich, J.R., 1994b. Crustal structure and tectonics of the southeastern Beaufort Sea continental margin, Tectonics, 13, 389-400, doi: 10.1029/93TC02251.

Stephenson, R., Piepjohn, K., Schiffer, C., von Gosen, W., and Oakey, G.N., this volume. Combined crustal-geological cross-section of Ellesmere Island, Geol. Soc. Spec. Publ.,.

Stoupakova, A.V., Henriksen, E., Burlin, Y.K., Larsen, G.B., Milne, J.K., Kiryukhina, T.A., Golynchik, P.O., Bordunov, S.I., Ogarkova, M.P., and Suslova, A.A., 2011. Chapter 21 The geological evolution and hydrocarbon potential of the Barents and Kara shelves, Geol. Soc. Lond. Mem., 35, 325-344, doi: 10.1144/M35.21.

Suckro, S.K., Gohl, K., Funck, T., Heyde, I., Ehrhardt, A., Schreckenberger, B., Gerlings, J., Damm, V., and Jokat, W., 2012. The crustal structure of southern Baffin Bay: Implications from a seismic refraction experiment, Geophys. J. Int., 190, 37-58, doi: 10.1111/j.1365246X.2012.05477.x.

Tegner, C., Brooks, C.K., Duncan, R.A., Heister, L.E., and Bernstein, S., 2008. 40Ar-39Ar ages of intrusions in East Greenland: Rift-to-drift transition over the Iceland hotspot, Lithos, 101, 480-500, doi: 10.1016/j.lithos.2007.09.001.

Tegner, C., and Pease, V., 2014. Continental Flood Basalts of Bennett Island, East Siberian Sea: High Arctic Geodynamics, in p. 2452.

Tegner, C., Storey, M., Holm, P.M., Thorarinsson, S.B., Zhao, X., Lo, C.-H., and Knudsen, M.F., 2011. Magmatism and Eurekan deformation in the High Arctic Large Igneous Province: 40Ar39Ar age of Kap Washington Group volcanics, North Greenland, Earth Planet. Sci. Lett., 303, 203-214, doi: 10.1016/j.epsl.2010.12.047.

Tessensohn, F., and Piepjohn, K., 2000. Eocene compressive deformation in Arctic Canada, North Greenland and Svalbard and its plate tectonic causes, Polarforschung, 68, 121-124.

Tessensohn, F., Piepjohn, K., Estrada, S., and Damaske, D., 2012. The German Arctic research program CASE: overview, results, perspectives, Z. Dtsch. Ges. Für Geowiss., 163, 205-231, doi: 10.1127/1860-1804/2012/0163-0205. 
Thorarinsson, S.B., Holm, P.M., Duprat, H.I., and Tegner, C., 2012. Petrology and Sr-Nd-Pb isotope geochemistry of Late Cretaceous continental rift ignimbrites, Kap Washington peninsula, North Greenland, J. Volcanol. Geotherm. Res., 219-220, 63-86, doi: 10.1016/j.jvolgeores.2012.01.011.

Thorarinsson, S.B., Holm, P.M., Tappe, S., Heaman, L.M., and Tegner, C., 2011. Late CretaceousPalaeocene continental rifting in the High Arctic: U-Pb geochronology of the Kap Washington Group volcanic sequence, North Greenland, J. Geol. Soc., 168, 1093-1106, doi: 10.1144/0016-76492011-018.

Thórarinsson, S.B., Söderlund, U., Døssing, A., Holm, P.M., Ernst, R.E., and Tegner, C., 2015. Rift magmatism on the Eurasia basin margin: $\mathrm{U}-\mathrm{Pb}$ baddeleyite ages of alkaline dyke swarms in North Greenland, J. Geol. Soc.,, 2015-049, doi: 10.1144/jgs2015-049.

Tomurtogoo, O., Windley, B.F., Kröner, A., Badarch, G., and Liu, D.Y., 2005. Zircon age and occurrence of the Adaatsag ophiolite and Muron shear zone, central Mongolia: constraints on the evolution of the Mongol-Okhotsk ocean, suture and orogen, J. Geol. Soc., 162, 125-134, doi: 10.1144/0016-764903-146.

Torsvik, T.H., and Andersen, T.B., 2002. The Taimyr fold belt, Arctic Siberia: timing of prefold remagnetisation and regional tectonics, Tectonophysics, 352, 335-348, doi: 10.1016/S0040-1951(02)00274-3.

Trettin, H.P., 1987. Pearya: a composite terrane with Caledonian affinities in northern Ellesmere Island, Can. J. Earth Sci., 24, 224-245, doi: 10.1139/e87-025.

Trettin, H.P., 1991a. Silurian-early Carboniferous deformational phases and associated metamorphism and plutonism, Arctic Island, in Trettin, H.P. ed., Geology of the Innuitian Orogen and Arctic Platform of Canada and Greenland, Geology of Canada 3, Geological Survey of Canada, p. 295-341.

Trettin, H.P., 1991b. Tectonic Framework, in Trettin, H.P. ed., Geology of the Innuitian Orogen and Arctic Platform of Canada and Greenland, Geology of Canada 3, Geological Survey of Canada, p. 57-66.

Trettin, H.P., and Parrish, R., 1987. Late Cretaceous bimodal magmatism, northern Ellesmere Island:isotopic age and origin, Can. J. Earth Sci., 24, 257-265, doi: 10.1139/e87-027.

Van Wagoner, N.A., Williamson, M.-C., Robinson, P.T., and Gibson, I.L., 1986. First samples of acoustic basement recovered from the alpha ridge, Arctic ocean: New constraints for the origin of the ridge, J. Geodyn., 6, 177-196, doi: 10.1016/0264-3707(86)90038-4.

Van Wijk, J.W., and Blackman, D.K., 2005. Dynamics of continental rift propagation: the endmember modes, Earth Planet. Sci. Lett., 229, 247-258, doi: 10.1016/j.epsl.2004.10.039.

Vol'nov, D.A., and Sorokov, D.S., 1961. Geology of Bennett Island: Akad. Nauk USSR Trans. Inst. Geol. Arktiki 123, 25 pp. p.

Walderhaug, H.J., Eide, E.A., Scott, R.A., Inger, S., and Golionko, E.G., 2005. Palaeomagnetism and 40Ar/39Ar geochronology from the South Taimyr igneous complex, Arctic Russia: a 
Middle-Late Triassic magmatic pulse after Siberian flood-basalt volcanism, Geophys. J. Int., 163, 501-517, doi: 10.1111/j.1365-246X.2005.02741.x.

Wang, Z., and Dahlen, F.A., 1995. Spherical-spline parameterization of three-dimensional earth models, Geophys. Res. Lett., 22, 3099-3102, doi: 10.1029/95GL03080.

Zhang, X., Omma, J., Pease, V., and Scott, R., 2013. Provenance of Late Paleozoic-Mesozoic Sandstones, Taimyr Peninsula, the Arctic, Geosciences, 3, 502-527, doi: 10.3390/geosciences3030502.

Zhang, X., Pease, V., Carter, A., Kostuychenko, Suleymanov, A., and Scott, R., this volume. Timing of exhumation and deformation across the Taimyr fold and thrust belt: Insight from apatite fission track dating and balanced cross-sections., Geol. Soc. Spec. Publ.,.

Zhang, X., Pease, V., Carter, A., and Scott, R., this volume. Exhumation history of Novaya Zemlya: New insights from geo- and thermochronology, Geol. Soc. Spec. Publ.,.

Zhang, X., Pease, V., Skogseid, J., and Wohlgemuth-Ueberwasser, C., 2015. Reconstruction of tectonic events on the northern Eurasia margin of the Arctic, from U-Pb detrital zircon provenance investigations of late Paleozoic to Mesozoic sandstones in southern Taimyr Peninsula, Geol. Soc. Am. Bull.,, B31241.1, doi: 10.1130/B31241.1.

Zienkiewicz, 1977. The Finite Element Method: McGraw-Hill, Maidenhead, Berkshire, England.

Zorin, Y.A., 1999. Geodynamics of the western part of the Mongolia-Okhotsk collisional belt, Trans-Baikal region (Russia) and Mongolia, Tectonophysics, 306, 33-56, doi: 10.1016/S0040-1951(99)00042-6. 
1252

1253

1254

1255

1256

1257

1258

1259

1260

1261

1262

1263

1264

1265

1266

1267

1268

1269

1270

1271

1272

1273

1274

1275

1276

1277

1278

1279

Figure 1: Circum Arctic overview maps. Left: Topography (ETOPO1) and geographical names. FJL - Franz Josef Land. NSI - New Siberian Islands. ERI - Ellef Ringnes Island. AHI - Axel Heiberg Island. EI - Ellesmere Island. JM - Jan Mayen. BI - Bel'Kov Island. MB - Makarov Basin. Red box (white box in printed version) - overview map in Figure 4. Right: Main tectonic features (after Pease et al. 2014) showing oceanic crust, cratons, fold belts, magmatic provinces (Thórarinsson et al., 2015) and continent-ocean boundaries (stippled where less constrained).

Figure 2: Crustal and lithospheric structure in the High Arctic. Datasets from LebedevaIvanova et al. (2016) and Schaeffer et al. (submitted). Structural features from Pease et al. (2014) (see also Fig. 1). Thick black lines - continent-ocean boundaries. Thin black line boundary of the Amerasia Basin. Red lines - volcanic rocks. Magenta - oceanic spreading ridge. Top Left: Sedimentary thickness; top right: Moho depth; bottom left: LAB depth; bottom right: sub-lithospheric pressure anomaly. BMS - Beaufort-Mackenzie Sea. CS Chukchi Sea. YKT - Yenesei-Khatanga Trough. KS - Kara Sea. EBS - East Barents Sea. WBS - West Barents Sea. LS - Lincoln Sea. BB - Baffin Bay. SB - Sverdrup basin.

Figure 3: Geopotential stress field and palaeo-stress in the High Arctic. Structural features as in Fig. 1. Top left: Geopotential energy model, corresponding Geoid anomaly, and computed compressive deviatoric stress directions (black lines). Top right: Computed compressive deviatoric stress directions (black lines) and underlying average stress directions of the World Stress Map (WSM; red lines). A contour map of the angular misfit is shown in the background. White areas indicate where the WSM has insufficient or no data. Only every fourth stress grid point is shown as black and red lines for clarity. Bottom left: High Arctic dykes (coloured lines) and magmatic provinces (red shading). HALIP 
dykes in the Canadian Arctic, Greenland, Svalbard and Franz Josef Land (green) are from (Buchan \& Ernst, 2006; Olesen et al., 2010; Døssing et al., 2013b; Polteau et al., 2016). The dykes and rift axis on Bennett Island are from this study. The late Cretaceous dyke swarms in North Greenland (orange) are from (Thórarinsson et al., 2015). The PermoTriassic on the Taimyr peninsula (blue) are from (Pease \& Vernikovsky, 2000; Walderhaug et al., 2005). The Permo-Triassic dykes in the Russian Arctic Islands (blue) are from (Kuzmichev \& Pease, 2007; Danukalova et al., 2014). Bottom right: Extensional structures (coloured dotted lines) as palaeo-stress markers. Late Cretaceous extensional structures in the Alpha Mendeleev Ridge/Eastern Amerasia Basin from (Døssing et al., 2013a). Rift systems in Northeast Greenland the western Barents Sea from (Faleide et al., 2008; Klitzke et al., 2015). Rift systems in the eastern Barents Sea from Marello et al. (2013). "Siberian Traps" rift systems after (Reichow et al., 2009). Cenozoic rift systems of the eastern Arctic Russian shelf from (Drachev, 2011). Palaeo-margins and spreading centre of the Canada Basin from (Grantz et al., 2011). Sverdrup Basin axis and Sverdrup Rim from (Embry, 1991). Wandel Sea Basin structures are from (Stemmerik et al., 1998). Banks Basin outline from (Trettin, 1991b). Amerasia Basin rift axes from (Nikishin, 2014).

\section{Figure 4: Comparison of the geopotential stress field using the geopotential energy to a} depth of $50 \mathrm{~km}$ (light grey) - representing mostly crustal structures - and to a depth of 100 $\mathrm{km}$ (black) - representing lithospheric structures - with a smoothed version of the World Stress Map (WSM, white). The shallow stress field (grey) and deep stress field (black) coincide very well in oceanic and intraplate areas, but deviate especially along the passive margins, such as the Chukchi margin to the Canada Basin, the Canadian polar margin, the East Siberian Sea and Laptev Sea, as well as the Barents Sea-North Atlantic margin and around Franz Josef Land. If differences are observed, the shallow stress field usually fits the WSM better than the deep stress field, especially in the western Barents Sea and the Canadian Arctic Archipelago. 
1313 Fig. 5: Bennett Island. A) Geological map of Bennett Island. Inset - overview map. Camera 1314 positions for B and C are indicated in A. B) Photo of Cape Emma with view to the 1315 northeast showing two dykes. C) Photo of Cape Sophia with view to the southeast showing 1316 a graben structure (indicated by black line), filled with flood basalts (see geological map in 1317 A).

1321 Figure 6: Interpretation of the lithospheric stress field after comparison with palaeo-stress 1322 markers (dykes and rift systems). Thick solid lines are areas of observed coincidence of 1323 structures and geopotential stress field and, therefore, indicating when the last modification 1324 of lithospheric structure has happened that gives rise to the geopotential stress field. Thick 1325 stippled lines indicate possible extended areas, where either no extensional structures are 1326 observed or where the age is unconstrained. 


$\begin{array}{lllllll}-4 & -3 & -2 & -1 & 0 & 1 & 2\end{array}$

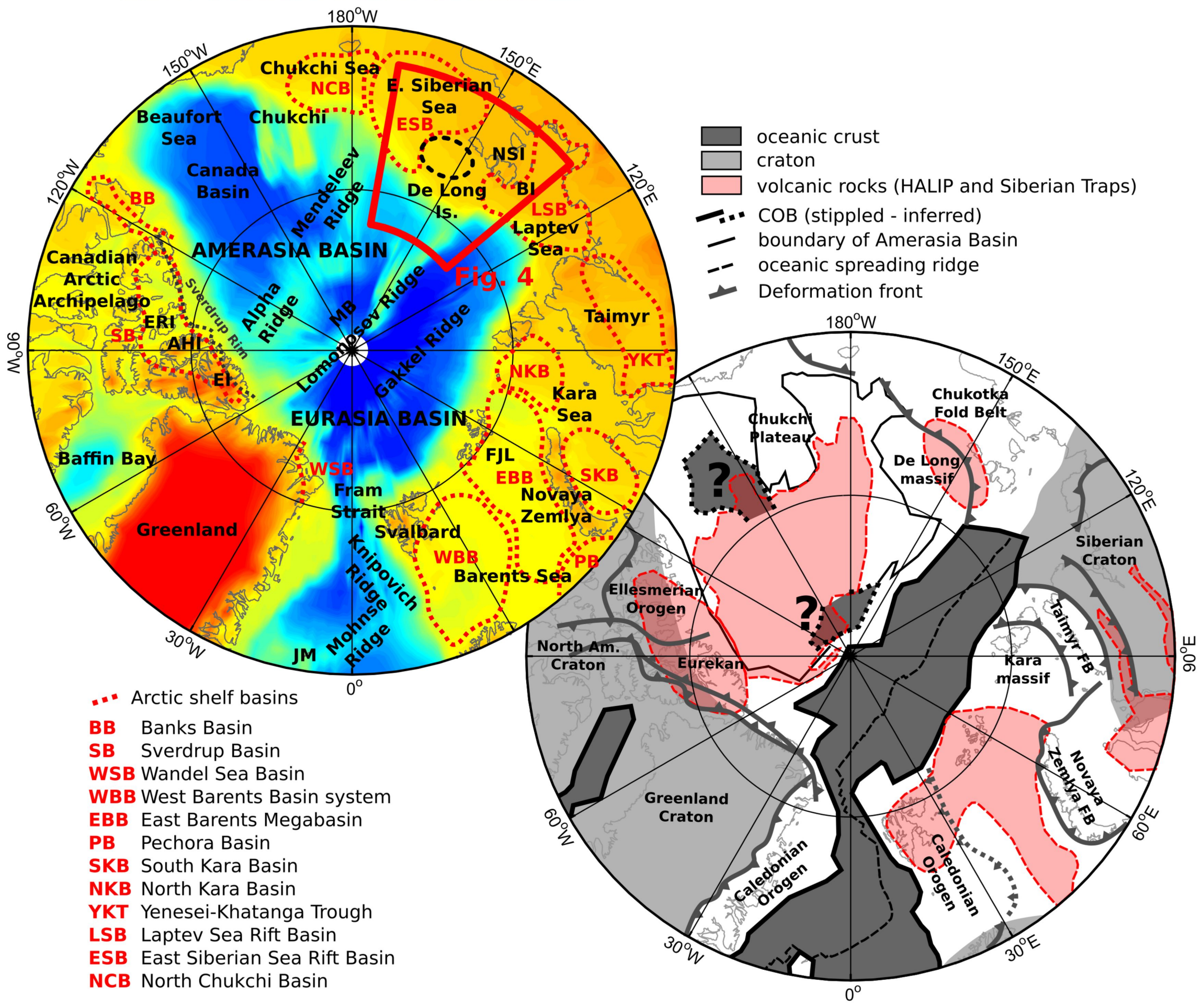


Sedimentary thickness [km]

\section{$\begin{array}{llllllll}2 & 4 & 6 & 8 & 10 & 12 & 14 & 16\end{array}$}

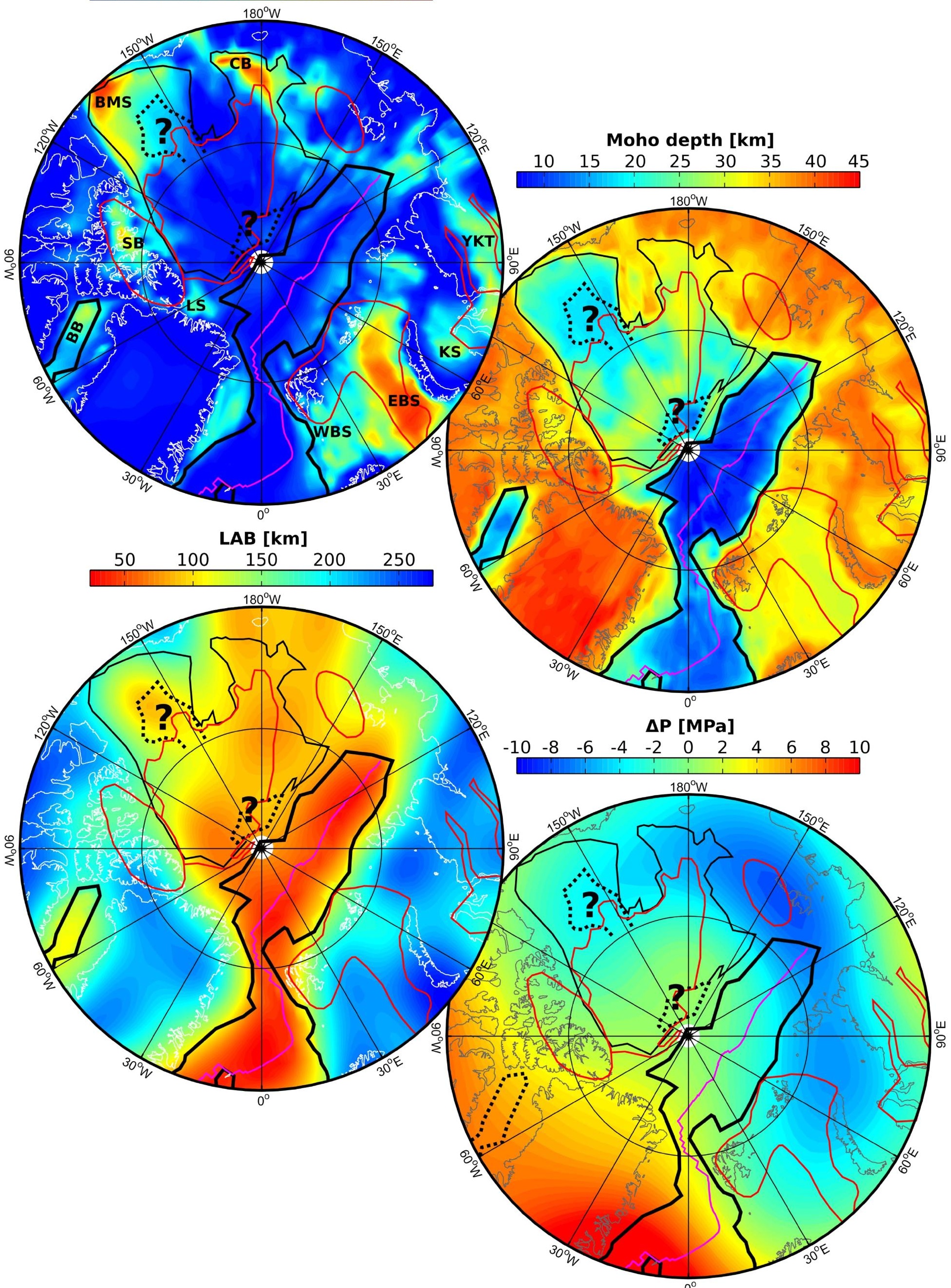



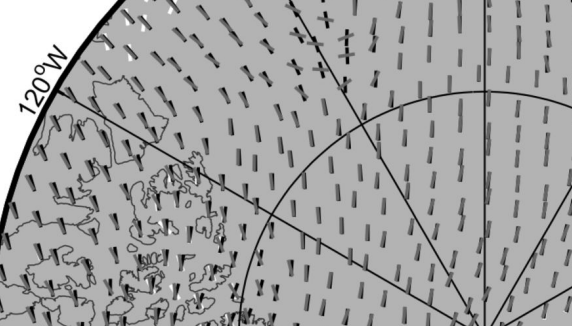

का

of

2)
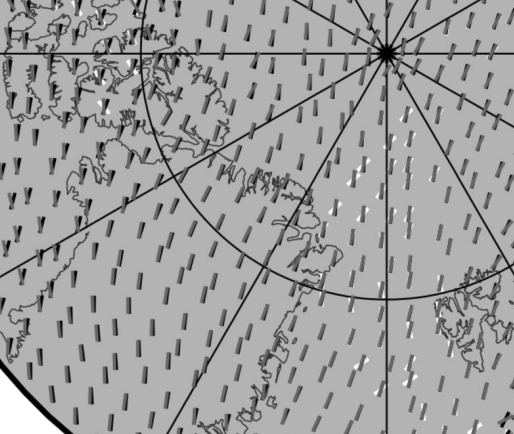

Prog

$11 / \frac{3+}{1}+$

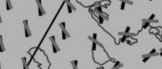

S of,

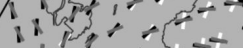

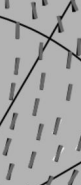

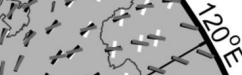
$x^{1}$

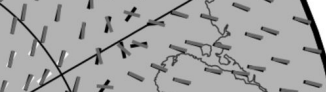

$11, x+5-1$ 


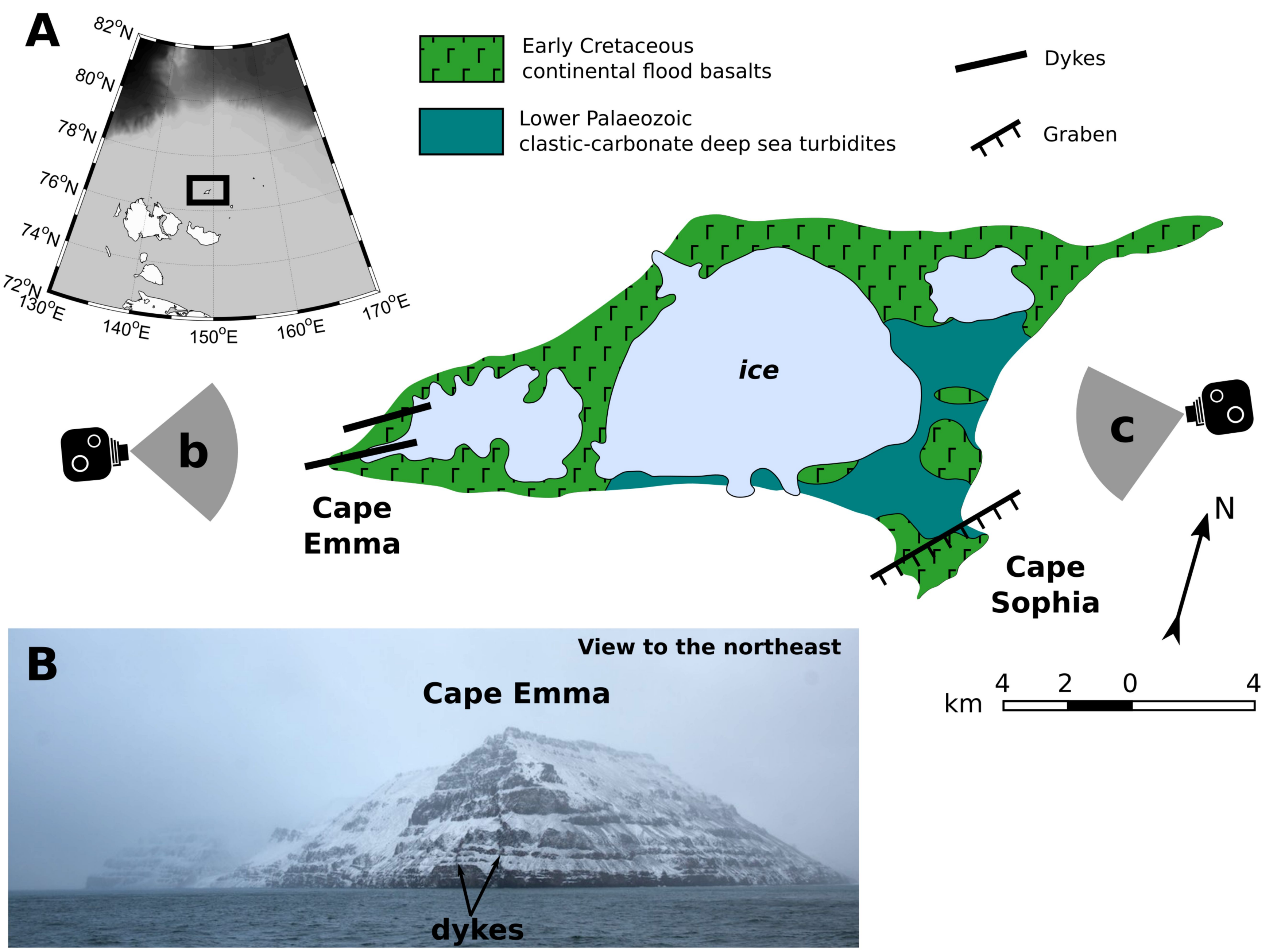

C

View to the southwest

\section{Cape Sophia}

\section{graben}




\section{Age of stress field}

\section{Ordovician-Carboniferous}

Permo-Triassic

Late Cretaceous

Early Cretaceous

Cenozoic

$180^{\circ} \mathrm{W}$

$150 \%$ a

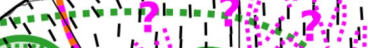

$\varphi$
$\vdots$
$\vdots$

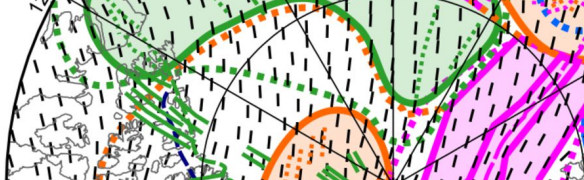

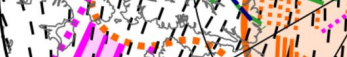

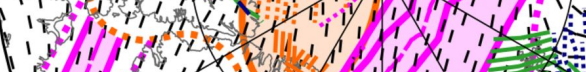

$\left\{\begin{array}{llll}1 & 1 \\ 1 & 1 & 1 & 1\end{array}\right.$ 8.

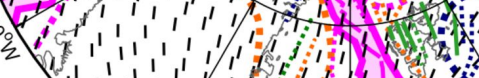

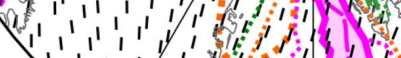

$x^{2}$ 